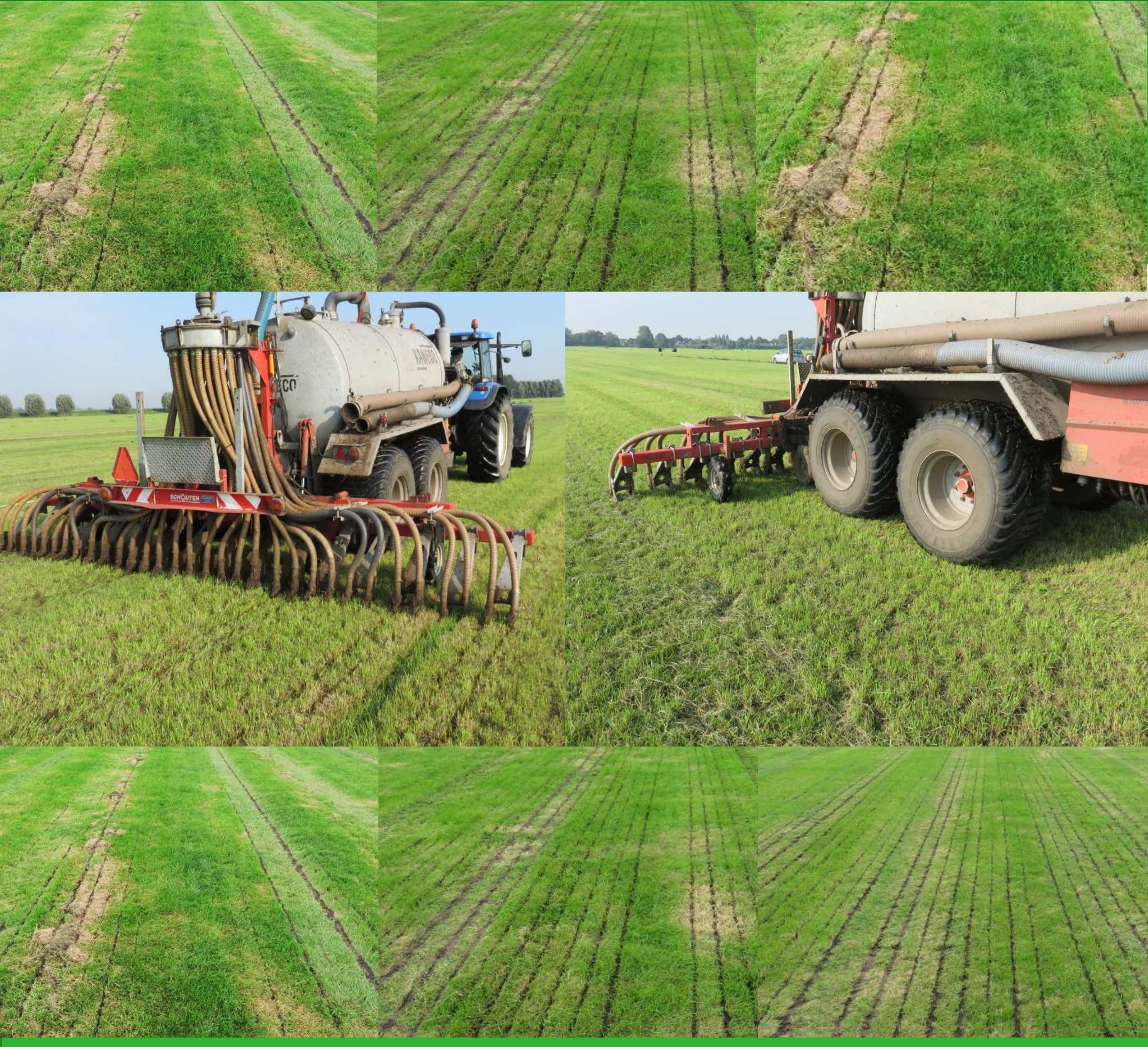

\title{
Ammoniakemissie bij met water verdunde mest toegediend met een sleepvoetenmachine op grasland
}

Resultaten 2016-2017 



\title{
Ammoniakemissie bij met water verdunde mest toegediend met een sleepvoetenmachine op grasland
}

\author{
Resultaten 2016-2017
}

J.F.M. Huijsmans ${ }^{1}$, J.M.G. Hol ${ }^{2}$, H.A. van Schooten ${ }^{2}$, B.R. Verwijs ${ }^{1}$

1 Wageningen Plant Research

2 Wageningen Livestock Research

Dit onderzoek is in opdracht van LTO Noord uitgevoerd door Wageningen Plant Research en Wageningen Livestock Research in het kader van Proeftuin Natura 2000, een samenwerkingsverband tussen LTO Noord, Projecten LTO Noord en Wageningen Universiteit \& Research.

Wageningen Research is een onderdeel van Wageningen University \& Research, samenwerkingsverband tussen Wageningen University en de Stichting Wageningen Research.

Wageningen, december 2017

Rapport 754 
Huijsmans, J.F.M., J.M.G. Hol, H.A. van Schooten \& B.R. Verwijs, 2017. Ammoniakemissie bij met water verdunde mest toegediend met een sleepvoetenmachine op grasland. Resultaten 2016-2017. Wageningen Research, Rapport WPR-754. 35 blz.; 5 fig.; 8 tab.; 8 ref.

Dit rapport is gratis te downloaden op https://doi.org/10.18174/444996

\section{Samenvatting:}

Voor het verder terugdringen van de ammoniakemissie bij mesttoediening is in 2013-2014 een eerste onderzoek uitgevoerd naar de emissie en grasopbrengst bij het uitrijden van met water verdunde mest met een sleepvoetenmachine. Hierbij werden relatief grote verdunningen toegepast. In 2016 en 2017 is uitgegaan van ook kleinere verdunningen. In 2016 werd onverdunde mest vergeleken met verdunde mest met een verdunningsfactor 1 deel mest : 0,25 deel water $(1: 0,25)$ en 1 deel mest met 0,5 deel water $(1: 0,5)$. In totaal werden twee proeven op veengrond en twee op kleigrond uitgevoerd gedurende het groeiseizoen. In 2017 werd onverdunde mest vergeleken met verdunde mest met een verdunningsfactor 1 deel mest : 0,33 deel water $(1: 0,33)$ in vier proeven op kleigrond.

De verdunningen van 1:0,25 en 1:0,5 in 2016 gaven een gemiddelde emissiereductie van respectievelijk 25 en $48 \%(n=3)$ ten opzichte van de onverdunde mest. In 2017 gaf een verdunning van $1: 0,33$ een gemiddelde emissiereductie van $21 \%(n=4)$.

Trefwoorden: sleepvoetenmachine, ammoniakemissie, mest, verdunnen, grasland

(C) 2017 Wageningen, Stichting Wageningen Research, Wageningen Plant Research, Agrosystems Research, Postbus 616, 6700 AP Wageningen; T 03174806 85; www.wur.nl/plant-research

KvK: 09098104 te Arnhem

VAT NL no. 8113.83.696.B07

Stichting Wageningen Research. Alle rechten voorbehouden. Niets uit deze uitgave mag worden verveelvoudigd, opgeslagen in een geautomatiseerd gegevensbestand, of openbaar gemaakt, in enige vorm of op enige wijze, hetzij elektronisch, mechanisch, door fotokopieën, opnamen of enige andere manier zonder voorafgaande schriftelijke toestemming van Stichting Wageningen Research.

Stichting Wageningen Research is niet aansprakelijk voor eventuele schadelijke gevolgen die kunnen ontstaan bij gebruik van gegevens uit deze uitgave.

\section{Rapport WPR-754}

Foto's omslag: Jan Huijsmans 



\section{Inhoud}

Woord vooraf

Samenvatting

Summary

10

1

Inleiding

12

2

Materiaal en methode

14

2.1 Opzet onderzoek

14

2.2 Meetmethode ammoniakemissie $\quad 14$

$\begin{array}{ll}2.3 \text { Metingen } & 15\end{array}$

2.4 Mesttoediening, mestgift en mestsamenstelling $\quad 16$

$\begin{array}{ll}2.5 & \text { Weersomstandigheden } \\ \end{array}$

3

$\begin{array}{lr}\text { Resultaten } & 19\end{array}$

$\begin{array}{lll}3.1 & \text { Mestsamenstelling en mestgift } & 19\end{array}$

$\begin{array}{lll}3.2 & \text { Ammoniakemissie } & 20\end{array}$

$\begin{array}{ll}\text { Discussie } & 25\end{array}$

$\begin{array}{llr}5 & \text { Conclusies en aanbevelingen } & 27\end{array}$

$\begin{array}{lr}\text { Literatuur } & 29\end{array}$

Bijlage 1 Weersomstandigheden tijdens de metingen in 2016

Bijlage 2 Weersomstandigheden tijdens de metingen in 201733 



\section{Woord vooraf}

Binnen de huidige regelgeving wordt aangegeven hoe mest emissiearm (ammoniak) toegediend dient te worden. Om een verdere emissiereductie te verkennen is door Wageningen UR een onderzoek verricht naar het effect van het verdunnen van de mest op de ammoniakemissie bij toediening met een sleepvoetenmachine. In 2013-2014 zijn eerste metingen uitgevoerd. In het voorliggende rapport wordt het vervolgonderzoek besproken dat in 2016-2017 is uitgevoerd. Opzet van het onderzoek, voortgang en resultaten zijn besproken binnen de projectgroep van Proeftuin Natura 2000 met vertegenwoordigers van LTO Noord, Projecten LTO Noord en WUR. Het onderzoek werd gefinancierd vanuit ZuivelNL, Melkveefonds en de LTO Noord Fondsen. 


\section{Samenvatting}

Om tegemoet te komen aan de vragen rondom een verder terugdringen van de ammoniakemissie bij mesttoediening is een vervolgonderzoek uitgevoerd bij het uitrijden van met water verdunde mest met een sleepvoetenmachine. Doelstelling was om de emissie vast te stellen bij verschillende niveaus van verdunnen van de mest.

De keuze voor het uitrijden van verdunde mest met een sleepvoetenmachine werd gemaakt, omdat bij de mesttoediening in het veenweidegebied en op zware klei regelmatig, met name in het voorjaar, de mest via een slang naar de toedieningsmachine wordt getransporteerd om zo het gebruik van een tank te voorkomen. Hierbij wordt vaak water gebruikt om de mest te verdunnen en daardoor beter verpompbaar te maken. In 2013-2014 is een eerste onderzoek uitgevoerd naar de ammoniakemissie en grasopbrengst bij uitrijden van verdunde mest met een sleepvoetenmachine. In dit onderzoek werden relatief grote verdunningen toegepast om vast te stellen of het verdunnen wel tot een substantiële emissiereductie kan leiden. In de voorliggende rapportage wordt het onderzoek uit 20162017 besproken, waarin is uitgegaan van ook kleinere verdunningen. In 2016 werd onverdunde mest vergeleken met verdunde mest met een verdunningsfactor 1 deel mest : 0,5 deel water $(1: 0,5)$ en 1 deel mest met 0,25 deel water $(1: 0,25)$ en in 2017 met verdunde mest met een verdunningsfactor 1 deel mest met 0,33 deel water $(1: 0,33)$.

De metingen werden in 2016 uitgevoerd op het Kennis Transfer Centrum (KTC) Zegveld (veengrond) en op een melkveehouderijbedrijf te Kamerik (kleigrond). In 2017 werden de metingen alleen uitgevoerd op de locatie op kleigrond. Binnen een proef werd steeds de ammoniakemissie gelijktijdig gemeten op één veld met niet verdunde mest en op één of twee velden met de verschillende verdunningen. De vergelijkende proeven zijn gespreid over het groeiseizoen uitgevoerd om zo wisselende omstandigheden in de proeven te betrekken. In alle metingen werd rundermest toegediend met sleepvoetenmachines. De ammoniakemissie werd gemeten met de micro-meteorologische massabalans methode. In totaal werden in 2016 twee proeven op kleigrond uitgevoerd en twee op veengrond en in 2017 vier op kleigrond.

In 2016 was de ammoniakemissie bij de toediening van de onverdunde mest gemiddeld $46 \%(n=3)$ en varieerde van 33 tot $62 \%$ van de toegediende ammoniumstikstof. Bij de verdunning 1 deel mest : 0,25 deel water $(1: 0,25)$ was de gemiddelde ammoniakemissie $32 \%(n=4)$ en varieerde van 27 tot $41 \%$ en bij 1 deel mest : 0,5 deel water $(1: 0,5)$ was de gemiddelde emissie $22 \%(n=4)$ en varieerde van 11 tot $32 \%$. De verdunningen van 1:0,25 en 1:0,5 gaven een gemiddelde emissiereductie van respectievelijk 25 en $48 \%(n=3)$.

In 2017 was de ammoniakemissie bij de toediening van de onverdunde mest gemiddeld $41 \%(n=4)$ en varieerde van 22 tot $56 \%$ van de toegediende ammoniumstikstof. Bij de verdunning 1 deel mest : 0,33 deel water $(1: 0,33)$ was de gemiddelde ammoniakemissie $31 \%(n=4)$ en varieerde van 20 tot $41 \%$. De verdunning van 1:0,33 gaf een gemiddelde emissiereductie van $21 \%(n=4)$.

Uit Huijsmans et al. (2015) en voorliggend onderzoek blijkt dat het emissieniveau bij grotere verdunningen $(1: 1$ en $1: 0,5)$ gemiddeld van een vergelijkbaar niveau is als bij zodenbemesting wordt aangehouden. In het onderzoek zijn echter geen rechtstreekse vergelijkende emissiemetingen uitgevoerd tussen zodenbemesting en toediening van met water verdunde mest met een sleepvoetenmachine.

De gemeten ammoniakemissie van de onverdunde mest was gemiddeld hoger dan in het verleden werd gevonden. Dit is mogelijk te verklaren door weers- en bodemomstandigheden, mestsamenstelling, toedieningsmethode en eventuele andere factoren die een rol hebben gespeeld. Om hier een beter zicht op te krijgen is een verdere statistische analyse naar invloedsfactoren noodzakelijk. 


\section{Summary}

Low-emission manure application techniques are compulsory in The Netherlands. Low emission manure application on grassland comprises shallow injection and narrow band application by trailing shoe. An additional reduction may be required in the future; therefore, new ways to reduce ammonia losses are investigated.

Field trials were carried out to get better knowledge on the ammonia volatilisation after the application of diluted manure applied in narrow band by trailing shoe on grassland on a clay and peat soil. In 2013-2014, first experiments were carried out with a relatively high dilution rate. In 2016 new experiments were carried out with dilution rates of 1 part manure : 0.25 part water $(1: 0.25)$ and 1 part manure : 0.5 part water $(1: 0.5)$ and in 2017 with the dilution rate of $1: 0.33$. In these emission experiments, dairy manure was used. The volatilization of $\mathrm{NH}_{3}$ was determined using the micrometeorological mass balance method. In the experiments in 2016, the dilution 1:0.25 resulted in an average emission reduction of $25 \%$ and the dilution 1:0.5 in an average emission reduction of $48 \%$ compared to non-diluted manure. In the experiments in 2017, the dilution 1:0.33 resulted in an average emission reduction of $21 \%$ compared to non-diluted manure.

The average ammonia emission of the non-diluted manure was higher than the average measured emission of manure application by trailing shoe in the past. Further analyses of all the influencing factors will be needed to clarify this difference. 


\section{$1 \quad$ Inleiding}

Nationaal staat het gebruik van de sleepvoetenmachine, die veel toegepast wordt op veengronden en zware kleigrond, onder druk tenzij stappen in een verdere emissiereductie gezet kunnen worden. Het streven hierbij is om te komen tot een emissieniveau dat lager of gelijk is aan de emissie bij zodenbemesting. Voor de veehouderij zijn de emissiereductie en efficiënte, betaalbare en werkbare uitrijmethoden van belang voor het besparen van de hoeveelheid kunstmest, het verhogen van de grasopbrengst en het open houden van extra ontwikkelingsruimte en ondernemersvrijheid voor veehouders in en rondom Natura 2000 gebieden.

In 2013-2014 is een eerste onderzoek uitgevoerd naar de emissie en grasopbrengst bij het uitrijden van met water verdunde mest met een sleepvoetenmachine (Huijsmans et al., 2015). In dit onderzoek werden relatief grote verdunningen toegepast om vast te stellen of het verdunnen wel tot een substantiële emissiereductie kan leiden. Bij deze relatief grote verdunningen ( 1 deel mest : 1 deel water en 1 deel mest : 0,5 deel water) werden gemiddelde emissiereducties bereikt van ca 50 en $40 \%$. Daarnaast werd in 2014 een oriënterend mestbenuttingsonderzoek op grasland uitgevoerd waarbij na de $2^{\mathrm{e}}$ snede eenmalig mest is aangewend met twee verschillende verdunningen. Verdunde mest met een verdunning van 1 deel mest : 0,5 deel water en 1 deel mest : 1 deel water leidde tot verhoogde opbrengsten ten opzichte van onverdunde mest van resp. $7-12 \%$ en $20-25 \%$ (Van Schooten et al., 2015). Het effect in dit onderzoek werd onderzocht bij een éénmalige toediening na de $2^{\mathrm{e}}$ snede onder relatief droge omstandigheden en zonder aanvulling van kunstmest-N.

De keuze voor het uitrijden van verdunde mest met een sleepvoetenmachine werd gemaakt, omdat bij de mesttoediening in het veenweidegebied en op zware kleigrond regelmatig, met name in het voorjaar, de mest via een slang naar de toedieningsmachine wordt getransporteerd om zo het gebruik van een tank te voorkomen. Hierbij wordt vaak water gebruikt om de mest te verdunnen en daardoor beter verpompbaar te maken.

In 2016 is een vervolgonderzoek uitgevoerd voor het vaststellen van jaarrond gewasopbrengst en stikstofbenutting door het gras bij toediening van verdunde mest met een sleepvoetenmachine bij verschillende verdunningen. De resultaten daarvan zijn beschreven in Van Schooten et al. (2017).

In de voorliggende rapportage worden de uitgevoerde emissieproeven in 2016 en 2017 besproken, waarin is uitgegaan van ook kleinere verdunningen. In 2016 werd onverdunde mest vergeleken met verdunde mest met een verdunningsfactor 1 deel mest : 0,5 deel water $(1: 0,5)$ en 1 deel mest met 0,25 deel water $(1: 0,25)$. In 2017 werd onverdunde mest vergeleken met verdunde mest met een verdunningsfactor 1 deel mest : 0,33 deel water $(1: 0,33)$. 


\section{Materiaal en methode}

\section{$2.1 \quad$ Opzet onderzoek}

De effecten van toedieningstechniek, mestdosering, veld- en weersomstandigheden op de ammoniakemissie kunnen verstrengeld zijn. De opzet van het onderzoek is gericht op het verkrijgen van inzicht in het effect van de verdunning door een vergelijking te maken tussen de emissie bij toediening van verdunde en onverdunde mest. Dit betekende dat gewerkt werd met één mestsoort en een vooraf gekozen mestdosering en dat de metingen op de velden met verdunde en onverdunde mest zoveel mogelijk gelijktijdig werden uitgevoerd. De metingen werden in 2016 uitgevoerd op KTC Zegveld te Zegveld (veengrond) en op een melkveehouderijbedrijf te Kamerik (kleigrond). In 2017 werden de metingen alleen uitgevoerd op de locatie op kleigrond.

In 2016 werd binnen een proef steeds op 3 velden de ammoniakemissie gemeten. Op één veld werd onverdunde mest uitgereden en op de andere velden werd verdunde mest in de verhouding 1 deel mest : 0,25 deel water $(1: 0,25)$ en verdunde mest in de verhouding 1 deel mest : 0,5 deel water $(1: 0,5)$ uitgereden. De mest werd op alle drie de velden toegediend met een sleepvoetenmachine. In alle metingen werd rundermest toegediend. Twee proeven werden op veengrond uitgevoerd en twee op kleigrond.

In 2017 werd binnen een proef steeds op 2 velden de ammoniakemissie gemeten. Op het ene veld werd onverdunde mest uitgereden en op het andere veld verdunde mest in de verhouding 1 deel mest : 0,33 deel water $(1: 0,33)$. De rundermest werd in deze proeven ook met een sleepvoetenmachine toegediend. In totaal werden vier proeven uitgevoerd op kleigrond.

\subsection{Meetmethode ammoniakemissie}

De ammoniakemissie werd gemeten met de micro-meteorologische massabalans methode. De micrometeorologische massabalansmethode berust op de vergelijking van de 'binnenkomende' ammoniakstroom (flux) met de 'uitgaande' ammoniakstroom (Denmead, 1983; Ryden and McNeill, 1984). Beide fluxen worden gemeten in een denkbeeldig verticaal vlak dat loodrecht staat op de gemiddelde windrichting. Bij deze meetmethode wordt een cirkelvormig bemest proefveld aangelegd van ca 0,15 ha, waarbij de meetmast die de uitgaande ammoniakflux meet in het midden van de cirkel wordt geplaatst (centrale mast). De binnenkomende ammoniakflux wordt gemeten met een mast die bovenwinds aan de rand van de cirkel staat (achtergrond mast). Figuur 1 toont een overzicht van de opstelling van een meting. Bij de centrale mast werden op 5 verschillende hoogtes (logaritmisch verdeeld) de bemonsteringspunten geplaatst (op ca. 0,3, 0,5, 1,0, 2,0 en 3,3 m boven maaiveld, +mv). Bij de achtergrondmast waren dit 3 meetpunten (op ca. 0,3, 2,0 en 3,3 m +mv).

De ammoniak in de lucht werd gemeten met behulp van een nat-chemische bemonsteringsmethode. Met impingers werd door middel van een pomp en aanzuigslangen circa 2,5 I min $\mathrm{m}^{-1}$ te bemonsteren lucht door gaswasflessen gevuld met $20 \mathrm{ml}$ absorptievloeistof $\left(0,02 \mathrm{M} \mathrm{HNO}_{3}\right)$ geleid. De ammoniakemissie na het toedienen van mest neemt exponentieel af in de tijd. Daarom werden de monsternameperiodes ingedeeld in de volgende tijdsperiodes (uren na toediening van de mest): $0-1$; $1-3 ; 3-6 ; 6-9 ; 9-24$ en 24-36, 36-48, 48-72 en 72-96 uur. Het ammoniumgehalte in de absorptievloeistof werd bepaald met een 'foto spectrometer'. De hoeveelheid bemonsterde lucht werd tweemaal per bemonsteringsperiode bepaald met behulp van rotorflowmeters.

De bemeste proefvelden van ca. 0,15 ha waren bij benadering rond (diameter ca. $45 \mathrm{~m}$ ), zodat bij verschillende windrichtingen de aanstroomlengte tot de centrale mast vrijwel gelijk bleef. Een cirkelvormig veld werd verkregen door de mest in banen uit te rijden. De lengte en breedte van deze banen werden opgemeten. 


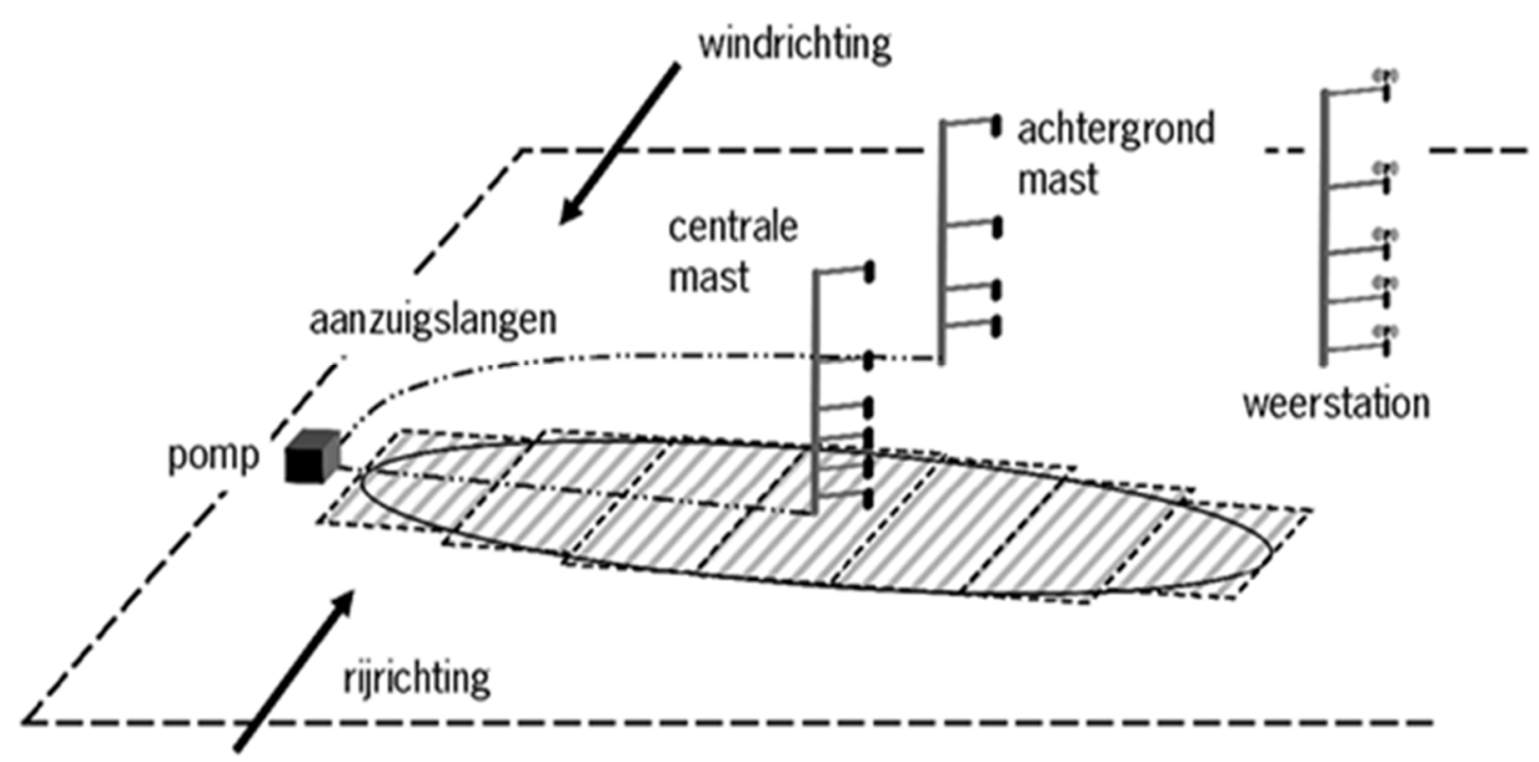

Figuur 1 Opbouw van een proefveld voor metingen volgens de micro-meteorologische massabalansmethode. Diameter proefveld ca. $45 \mathrm{~m}$.

Met de gemeten ammoniakconcentraties werd per monsternameperiode het concentratieprofiel bepaald, waarbij de concentratie afneemt met de hoogte van het monsternamepunt op de meetmast. Het concentratieprofiel werd gecorrigeerd voor de gemiddelde inkomende ammoniakflux (achtergrondmast bovenwinds), waarbij de ammoniakconcentratie voor alle drie de monsternamepunten ongeveer gelijk is. Tegelijkertijd werd per monsternameperiode op verschillende hoogten de windsnelheid gemeten, waarmee een windprofiel kon worden opgesteld. Met de gemeten windrichting en de afmetingen van een proefveld werd per monsternameperiode de gemiddelde aanstroomlengte (fetch) tot de centrale mast bepaald. Vervolgens werd met het concentratie- en windprofiel en de fetch, de emissie per monsternameperiode berekend (Denmead, 1983; Ryden and McNeill, 1984). De emissie per meetinterval wordt weergegeven als percentage van de met de mest toegediende ammoniumstikstof $\left(\mathrm{NH}_{4}-\mathrm{N}\right)$. De totale (cumulatieve) emissie gedurende een meetsessie wordt verkregen door optelling van de bepaalde emissies in de aaneengesloten meetintervallen.

\section{$2.3 \quad$ Metingen}

Een meting van de ammoniakemissie startte direct na toediening van de mest en duurde tot 4 dagen per proef. Het eerder stoppen van een meting vond plaats wanneer er bijvoorbeeld in korte tijd overvloedige neerslag optrad. De metingen werden gespreid over het groeiseizoen uitgevoerd om zo ook verschillende veld- en weersomstandigheden binnen de metingen te betrekken. Tabel 1 en 2 geven een overzicht van de uitgevoerde metingen in 2016 en 2017.

In 2016 is de eerste proef op veengrond uitgevoerd voorafgaand aan de groeiperiode van de eerste snede en de tweede proef na de oogst van de eerste snede. Op de kleigrond is de eerste proef aangelegd na oogst van de eerste snede en de tweede proef na de oogst van de vierde snede. Bij de tweede proef op veengrond waren er problemen bij het uitrijden van de onverdunde mest (referentieveld). De problemen resulteerden in een zeer onregelmatige verdeling van de mest met op grote delen van het proefveld geen mest. De emissiemetingen aan dit veld zijn wel uitgevoerd, maar verder niet geanalyseerd (te slechte mesttoediening; een vereiste bij de meetprocedure is dat mest goed verdeeld is over het proefveld); het mestmonster is wel geanalyseerd ter controle van de gemaakte verdunningen. In 2017 zijn de metingen uitgevoerd na de $1^{\mathrm{e}}$ (proef 1 en 2 ), $2^{\mathrm{e}}$ en de $4^{\mathrm{e}}$ snede. 
Tabel 1 Tijdstip, proef en grondsoort, verdunningen, begin- en eindtijdstippen van de proeven in 2016.

\begin{tabular}{|c|c|c|c|c|c|c|}
\hline Week-jaar & $\begin{array}{l}\text { Proefnummer } \\
\text { en grondsoort }\end{array}$ & Verdunning & Startdatum & $\begin{array}{l}\text { Starttijdstip } \\
\text { (uur:min) }\end{array}$ & Einddatum & $\begin{array}{l}\text { Eindtijdstip } \\
\text { (uur:min) }\end{array}$ \\
\hline \multirow[t]{3}{*}{$14-2016$} & 1 veen ${ }^{1)}$ & Onverdund & $06-04-2016$ & $10: 50$ & 07-04-2016 & $18: 01$ \\
\hline & & $1: 0,25$ & & 09:56 & & $17: 53$ \\
\hline & & $1: 0,5$ & & $10: 18$ & & $18: 11$ \\
\hline \multirow[t]{3}{*}{$20-2016$} & 2 klei & Onverdund & $17-05-2016$ & $11: 06$ & $20-05-2016$ & $18: 27$ \\
\hline & & $1: 0,25$ & & $10: 02$ & & $18: 13$ \\
\hline & & $1: 0,5$ & & $10: 18$ & & $18: 19$ \\
\hline \multirow[t]{3}{*}{$21-2016$} & 3 veen & Onverdund & $24-05-2016$ & 09:03 & $28-05-2016$ & $10: 06$ \\
\hline & & $1: 0,25$ & & $07: 43$ & & 09:08 \\
\hline & & $1: 0,5$ & & $08: 16$ & & $10: 01$ \\
\hline \multirow[t]{3}{*}{$33-2016$} & $4 \mathrm{klei}^{2)}$ & Onverdund & $19-08-2016$ & $10: 53$ & $21-08-2016$ & $19: 23$ \\
\hline & & $1: 0,25$ & & $09: 23$ & & $19: 18$ \\
\hline & & $1: 0,5$ & & 09:42 & & $19: 10$ \\
\hline
\end{tabular}

1) eerder gestopt vanwege langdurige regen

2) eerder gestopt vanwege hevige regen

Tabel 2 Tijdstip, proef en grondsoort, verdunningen, begin- en eindtijdstippen van de proeven in 2017.

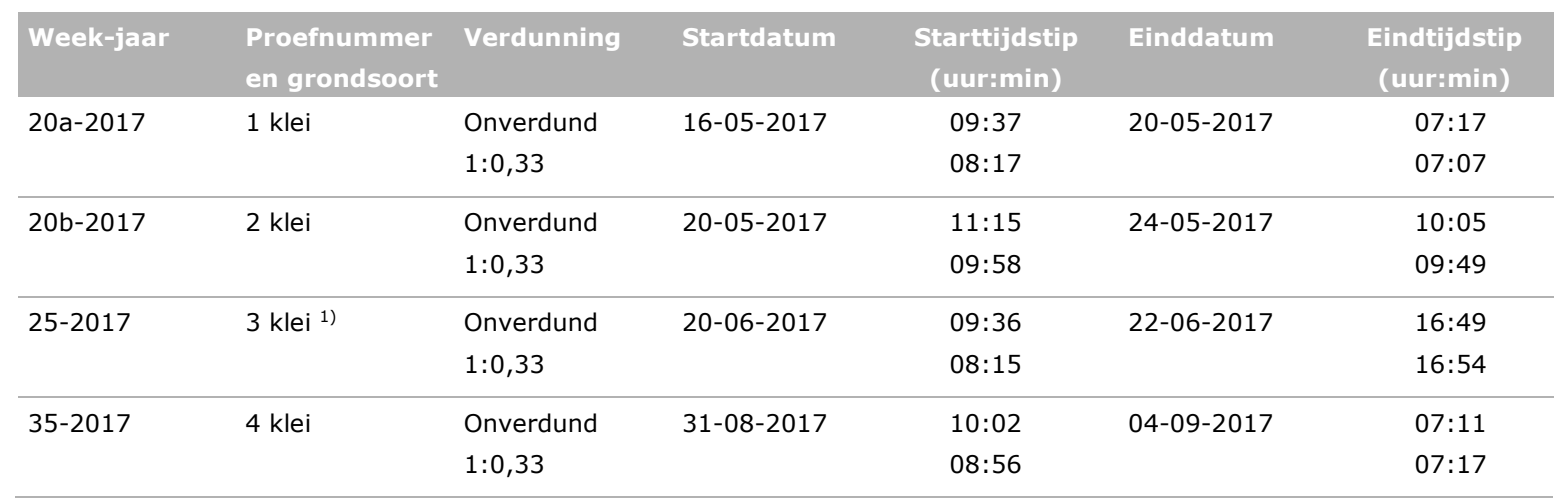

1) eerder gestopt vanwege opkomend onstuimig weer (onweer, hevige regen)

\subsection{Mesttoediening, mestgift en mestsamenstelling}

In alle metingen is uitgegaan van rundermest en een mestgift van circa $20 \mathrm{~m}^{3} \mathrm{ha}^{-1}$ onverdunde mest. Voor de verdunde mest werd een gift van circa $30 \mathrm{~m}^{3}$ ha-1 bij de 1:0,5 verdunning, $25 \mathrm{~m}^{3} \mathrm{ha}^{-1}$ bij de $1: 0,25$ verdunning en ca $27 \mathrm{~m}^{3} \mathrm{ha}^{-1}$ bij de 1:0,33 verdunning aangehouden om zo een vergelijkbare stikstof/ammonium gift te creëren als met de onverdunde mest.

De verdunde mest werd bij iedere meetserie vlak voor het uitrijden aangemaakt door weging van de hoeveelheid mest en water in de tank op een weegbrug. Het toedienen van de mest werd uitgevoerd met praktijkmachines: een getrokken tank met een 6 meter brede sleepvoetenmachine en een getrokken tank met een 5,2 meter brede sleepvoetenmachine (Figuur 2 en Figuur 3) in 2016 en de 5,2 m sleepvoetenmachine in 2017. De sleepvoetenmachines waren van eenzelfde merk en type. Voorafgaand aan de aanleg van ieder proefveld werd de totale combinatie van trekker en mesttank met de verdunde of onverdunde mest gewogen. Na het bemesten van een proefveld werd de totale machine nogmaals gewogen. Uit het verschilgewicht en de afmetingen van het proefveld werd de mestgift bepaald. Per proefveld werden twee mestmonsters genomen tijdens of direct na de aanleg van de proefvelden aan de uitloop van de sleepvoeten. De mestmonsters werden geanalyseerd op $\mathrm{NH}_{4}-\mathrm{N}, \mathrm{N}$ totaal, drogestofgehalte en $\mathrm{pH}$. 


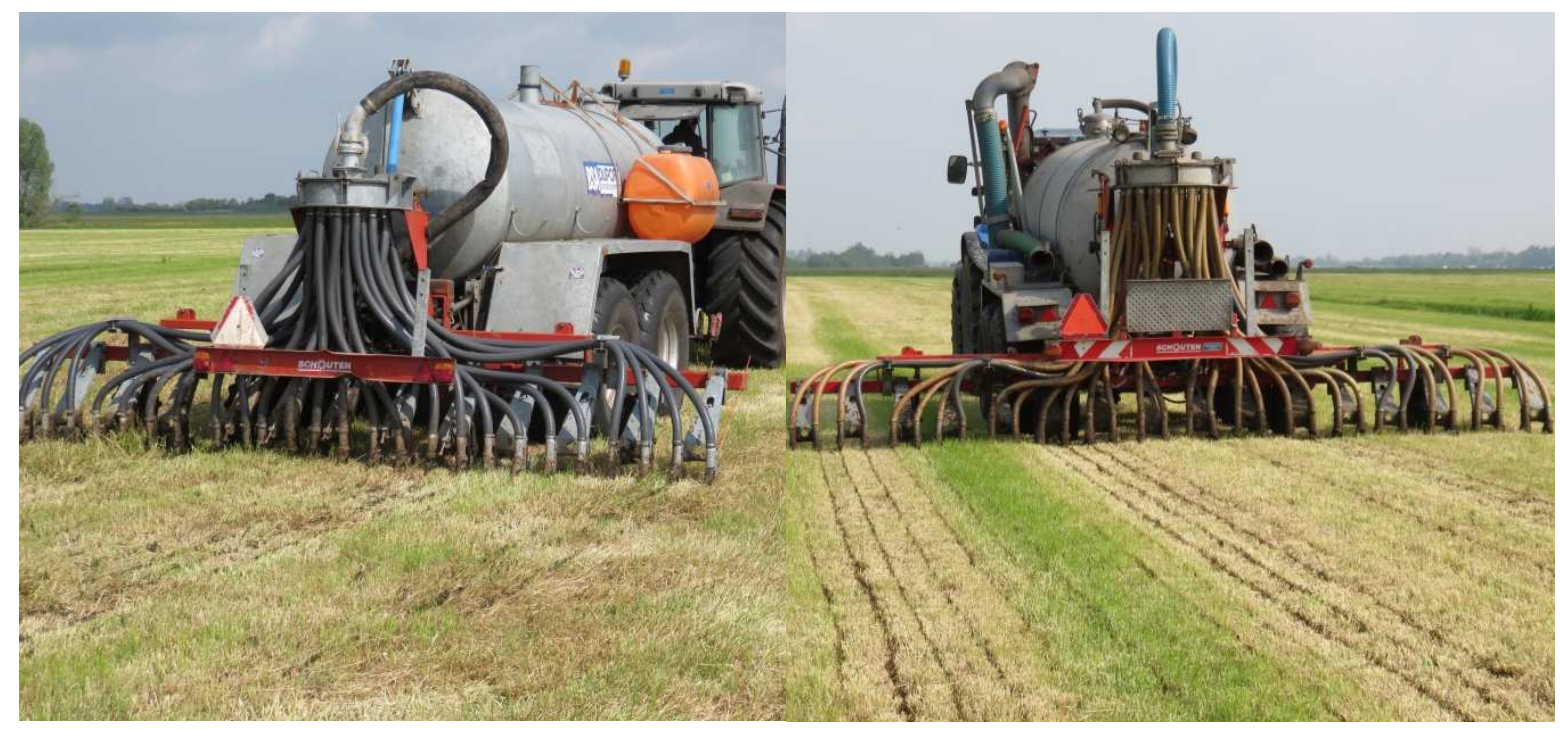

Figuur 2 Toegepaste bemesters voor het uitrijden van niet verdunde mest (links) en verdunde mest (rechts).

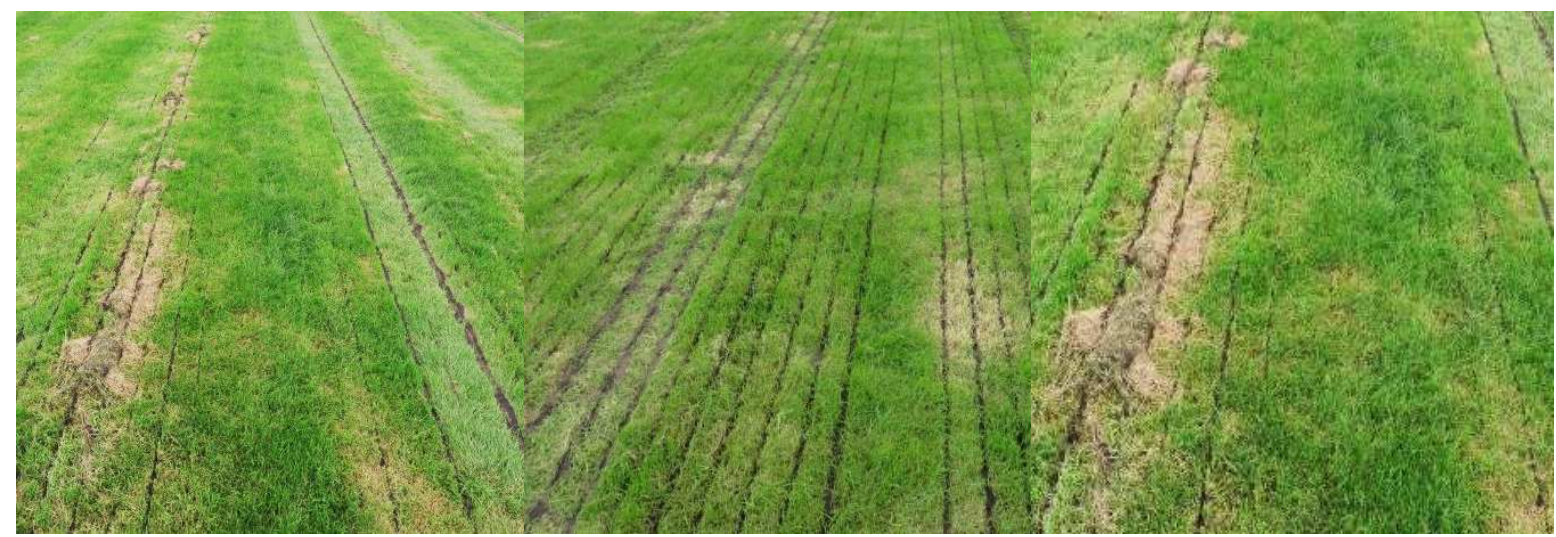

Figuur 3 Mesttoediening niet verdunde mest (links) en detail van toediening verdunde mest 1:0,5 (midden) en verdunde mest 1:0,25 (rechts).

\subsection{Weersomstandigheden}

Om de emissie van een proefveld te kunnen berekenen werd naast, de ammoniakconcentratie, de windsnelheid en de windrichting bepaald. Ook werd per experiment de temperatuur en relatieve luchtvochtigheid van de buitenlucht en de hoeveelheid neerslag geregistreerd. Gedurende een gehele meetsessie werd de windsnelheid met behulp van cup-anemometers (Vector Instruments type A100R) op 6 hoogtes (logaritmisch verdeeld) gemeten. De gemiddelde meethoogten waren 0,30,0,45, 0,90, $1,40,2,40$ en 3,65 m +mv. De windrichting werd op 3,7 m hoogte gemeten (Vector Instruments W200P). De temperatuur en relatieve luchtvochtigheid werden met een rotronic (Hygromer) op 1,5 m hoogte bepaald. De neerslag werd op 0,2 m hoogte bepaald met een regenmeter. De weersgegevens werden verzameld met behulp van een datalogger, waarin de gemiddelden van de waarnemingen iedere 15 minuten werden opgeslagen. In Bijlage 1 en 2 worden de weersomstandigheden gedurende de perioden van de ammoniakemissiemetingen weergegeven. In Tabel 3 en 4 staan de gemiddelde weergegevens van de eerste 9 uur na de mesttoediening en de hoeveelheid neerslag gedurende de totale meetperiode weergegeven. 
Tabel 3 Gemiddelde windsnelheid $\left(\mathrm{m} \mathrm{s}^{-1}\right)$ op ca. $2 \mathrm{~m}$ hoogte, temperatuur $\left({ }^{\circ} \mathrm{C}\right)$ en relatieve luchtvochtigheid (\%) gedurende de eerste 9 uur na toedienen van de mest en de hoeveelheid neerslag $(\mathrm{mm})$ gedurende de gehele meetperiode voor iedere proef in 2016.

\begin{tabular}{|c|c|c|c|c|c|}
\hline Week-jaar & $\begin{array}{l}\text { Proefnummer en } \\
\text { grondsoort }\end{array}$ & $\begin{array}{l}\text { Wind } \\
\left(\mathrm{m} \mathrm{s}^{-1}\right)\end{array}$ & $\begin{array}{c}\mathrm{T} \\
\left({ }^{\circ} \mathrm{C}\right)\end{array}$ & $\begin{array}{c}\text { RV } \\
(\%)\end{array}$ & $\begin{array}{c}\text { Neerslag } \\
(\mathrm{mm})\end{array}$ \\
\hline $14-2016$ & 1 veen & 7,6 & 10,3 & 83 & $11,8^{1)}$ \\
\hline $20-2016$ & 2 klei & 3,9 & 16,9 & 57 & 9,8 \\
\hline $21-2016$ & 3 veen & 4,7 & 13,3 & 70 & 4,4 \\
\hline
\end{tabular}

1) totale meetperiode 32 uur

2) totale meetperiode 58 uur

Tabel 4 Gemiddelde windsnelheid $\left(\mathrm{m} \mathrm{s}^{-1}\right)$ op ca. $2 \mathrm{~m}$ hoogte, temperatuur $\left({ }^{\circ} \mathrm{C}\right)$ en relatieve luchtvochtigheid (\%) gedurende de eerste 9 uur na toedienen van de mest en de hoeveelheid neerslag $(\mathrm{mm})$ gedurende de gehele meetperiode voor iedere proef in 2017.

\begin{tabular}{|c|c|c|c|c|c|}
\hline Week-jaar & $\begin{array}{l}\text { Proefnummer en } \\
\text { grondsoort }\end{array}$ & $\begin{array}{l}\text { Wind } \\
\left(\mathrm{m} \mathrm{s}^{-1}\right)\end{array}$ & $\begin{array}{c}\mathrm{T} \\
\left({ }^{\circ} \mathrm{C}\right)\end{array}$ & $\begin{array}{l}\text { RV } \\
(\%)\end{array}$ & $\begin{array}{c}\text { Neerslag } \\
(\mathrm{mm})\end{array}$ \\
\hline $20 a-2017$ & $1 \mathrm{klei}$ & 3,5 & 24,7 & 54 & 2,8 \\
\hline $20 b-2017$ & 2 klei & 3,0 & 16,2 & 64 & 0 \\
\hline $25-2017$ & 3 klei $^{1)}$ & 4,2 & 25,3 & 70 & 0 \\
\hline $35-2017$ & 4 klei & 2,8 & 17,7 & 77 & 0,7 \\
\hline
\end{tabular}

1) totale meetperiode 56 uur 


\section{Resultaten}

\subsection{Mestsamenstelling en mestgift}

In Tabel 5 en 6 is de mestgift en de gemiddelde mestsamenstelling per proef en per proefveld gegeven. De beoogde mestgiften en verhoudingen tussen de giften (20, 25, 27 en $30 \mathrm{~m}^{3} \mathrm{ha}^{-1} \mathrm{bij}$ respectievelijk onverdund, $1: 0,25,1: 0,33$ en 1:0,5) werden niet in alle gevallen goed gerealiseerd met de praktijkmachines. Aan de hand van de mestanalyses kan geconcludeerd worden dat de verdunningen goed gelukt zijn. De relatieve gehalten bij de verdunningen in 2016 (gehalte verdund/gehalte onverdund) waren bij de 1:0,25 verdunning 79\% (beoogd $80 \%$ ) en bij de 1:0,50 verdunning 63\% (beoogd 66,6\%). De relatieve gehalten bij de verdunningen in 2017 (gehalte verdund/gehalte onverdund) waren bij de 1:0,33 verdunning gemiddeld $75 \%$ (beoogd $75 \%$ ).

Tabel 5 Mestgift en samenstelling van de onverdunde en verdunde mest in $2016^{1)}$.

\begin{tabular}{|c|c|c|c|c|c|c|c|c|}
\hline $\begin{array}{l}\text { Week- } \\
\text { jaar }\end{array}$ & $\begin{array}{l}\text { Proefnummer } \\
\text { en grondsoort }\end{array}$ & Verdunning & $\begin{array}{l}\text { Mestgift } \\
\left(\mathrm{m}^{3} h \mathrm{a}^{-1}\right)\end{array}$ & $\begin{array}{c}\text { Mestgift } \\
\left(\mathrm{kg} \mathrm{NH}_{4}-\mathrm{N} \mathrm{ha}^{-1}\right)\end{array}$ & $\begin{array}{c}\mathrm{NH}_{4}-\mathrm{N} \\
\left(\mathrm{g} \mathrm{kg}^{-1}\right)\end{array}$ & $\begin{array}{l}\text { Ntotaal } \\
\left(\mathrm{g} \mathrm{kg}^{-1}\right)\end{array}$ & $\begin{array}{l}\text { Ds } \\
(\%)\end{array}$ & $\mathrm{pH}$ \\
\hline \multirow[t]{3}{*}{$14-2016$} & 1 veen & Onverdund & 22,9 & 45,9 & 2,00 & 4,34 & 8,8 & 7,2 \\
\hline & & $1: 0,25$ & 24,2 & 39,0 & 1,61 & 3,49 & 7,0 & 7,2 \\
\hline & & $1: 0,5$ & 35,5 & 46,4 & 1,31 & 2,83 & 5,6 & 7,3 \\
\hline \multirow[t]{3}{*}{$20-2016$} & 2 klei & Onverdund & 26,3 & 57,1 & 2,17 & 4,60 & 9,0 & 7,2 \\
\hline & & $1: 0,25$ & 21,0 & 36,1 & 1,72 & 3,60 & 7,1 & 7,1 \\
\hline & & $1: 0,5$ & 35,4 & 45,0 & 1,27 & 2,65 & 5,1 & 7,2 \\
\hline \multirow[t]{3}{*}{$21-2016$} & 3 veen & Onverdund & & & 1,70 & 4,00 & 9,4 & 7,0 \\
\hline & & $1: 0,25$ & 23,3 & 31,5 & 1,31 & 3,07 & 7,1 & 7,0 \\
\hline & & $1: 0,5$ & 28,9 & 31,9 & 1,10 & 2,59 & 5,7 & 7,1 \\
\hline \multirow[t]{3}{*}{$33-2016$} & 4 klei & Onverdund & 21,9 & 38,7 & 1,77 & 3,21 & 5,1 & 7,5 \\
\hline & & $1: 0,25$ & 27,5 & 39,1 & 1,42 & 2,60 & 4,2 & 7,4 \\
\hline & & $1: 0,5$ & 24,0 & 28,2 & 1,17 & 2,16 & 3,5 & 7,4 \\
\hline
\end{tabular}

1) resultaten mestanalyses zijn het gemiddelde van 2 mestmonsters genomen tijdens het uitrijden

Tabel 6 Mestgift en samenstelling van de onverdunde en verdunde mest in $2017^{11)}$

\begin{tabular}{|c|c|c|c|c|c|c|c|c|}
\hline $\begin{array}{l}\text { Week- } \\
\text { jaar }\end{array}$ & $\begin{array}{l}\text { Proefnummer } \\
\text { en grondsoort }\end{array}$ & Verdunning & $\begin{array}{l}\text { Mestgift } \\
\left(\mathrm{m}^{3} h \mathrm{a}^{-1}\right)\end{array}$ & $\begin{array}{c}\text { Mestgift } \\
\left(\mathrm{kg} \mathrm{NH}_{4}-\mathrm{N} \mathrm{ha}^{-1}\right)\end{array}$ & $\begin{array}{l}\mathrm{NH}_{4}-\mathrm{N} \\
\left(\mathrm{g} \mathrm{kg}^{-1}\right)\end{array}$ & $\begin{array}{l}\text { Ntotaal } \\
\left(\mathrm{g} \mathrm{kg}^{-1}\right)\end{array}$ & $\begin{array}{l}\text { Ds } \\
(\%)\end{array}$ & $\mathrm{pH}$ \\
\hline \multirow[t]{2}{*}{$20 a-2017$} & $1 \mathrm{klei}$ & Onverdund & 21,5 & 39,0 & 1,82 & 3,64 & 6,8 & 7,2 \\
\hline & & $1: 0,33$ & 24,8 & 32,0 & 1,29 & 2,61 & 4,9 & 7,2 \\
\hline \multirow[t]{2}{*}{$20 b-2017$} & 2 klei & Onverdund & 20,7 & 38,6 & 1,87 & 3,74 & 6,8 & 7,2 \\
\hline & & $1: 0,33$ & 27,1 & 37,4 & 1,38 & 2,79 & 5,1 & 7,3 \\
\hline \multirow[t]{2}{*}{$25-2017$} & 3 klei & Onverdund & 17,3 & 25,6 & 1,48 & 3,46 & 7,4 & 6,9 \\
\hline & & $1: 0,33$ & 19,5 & 21,6 & 1,11 & 2,61 & 5,6 & 6,9 \\
\hline \multirow[t]{2}{*}{$35-2017$} & 4 klei & Onverdund & 22,0 & 29,8 & 1,36 & 2,65 & 5,0 & 7,4 \\
\hline & & $1: 0,33$ & 27,4 & 28,1 & 1,03 & 2,10 & 4,0 & 7,3 \\
\hline
\end{tabular}

1) resultaten mestanalyses zijn het gemiddelde van 2 mestmonsters genomen tijdens het uitrijden 


\subsection{Ammoniakemissie}

Tijdens een meting werd gedurende een periode, direct volgend op het tijdstip van de mesttoediening, de ammoniakemissie gemeten. In Tabel 7 staat de totaal gemeten ammoniakemissie voor de verschillende proefvelden in 2016 weergegeven en in Figuur 4 staan de gemeten emissieverlopen voor de proeven uitgevoerd op veengrond en kleigrond. In Tabel 8 en Figuur 5 staan de resultaten van de metingen in 2017.

In 2016 werden proef 1 en 4 eerder afgesloten als gevolg van langdurige regen en hevige regen. Voor proef 1 was dit na 32 uur en bij proef 4 was dit na 58 uur. Door een technische storing bij proef 3 is de laatste meetperiode van het veld met de 1:0,25 verdunning komen te vervallen. Alle metingen gaven het karakteristieke beeld van een verloop van de ammoniakemissie na mesttoediening: gedurende de eerste dag na toediening (de eerste 9 uur overdag) vond een groot aandeel van de emissie plaats. In 2017 werd proef 3 na 56 uur gestopt vanwege onstuimig weer (onweer, hevige regen).

In 2016 was de ammoniakemissie bij de toediening van de onverdunde mest gemiddeld $46 \%(n=3$; proef 3 uitgevallen) en varieerde van 33 tot $62 \%$ van de toegediende ammoniumstikstof. Bij de verdunning 1 deel mest : 0,25 deel water $(1: 0,25)$ was de gemiddelde ammoniakemissie $32 \%(n=4)$ en varieerde van 27 tot $41 \%$ en bij 1 deel mest : 0,5 deel water $(1: 0,5)$ was de gemiddelde ammoniakemissie $22 \%(n=4)$ en varieerde van 11 tot $32 \%$. De verdunning van 1:0,25 en $1: 0,5$ gaven een gemiddelde emissiereductie van respectievelijk 25 en $48 \%(n=3)$.

In 2017 was de gemiddelde ammoniakemissie bij de onverdunde mest gemiddeld $41 \%(n=4)$ en varieerde van 22 tot $56 \%$ van de toegediende ammoniumstikstof. Bij de verdunning 1 deel mest : 0,33 deel water $(1: 0,33)$ was de gemiddelde ammoniakemissie $31 \%(n=4)$ en varieerde van 20 tot $41 \%$. De verdunning van 1:0,33 gaf een gemiddelde emissiereductie van $21 \%(n=4)$.

Tabel 7 Cumulatieve emissie over de gemeten periode na uitrijden van de mest als \% van de opgebrachte ammoniumstikstof $\mathrm{NH}_{4}-\mathrm{N}$ en de emissiereductie die bereikt wordt bij 1:0,25 en 1:0,5 verdunning van de mest ten opzichte van onverdunde mest in 2016.

\begin{tabular}{|c|c|c|c|c|}
\hline $\begin{array}{l}\text { Week- } \\
\text { jaar }\end{array}$ & $\begin{array}{l}\text { Proefnummer en } \\
\text { grondsoort }\end{array}$ & Verdunning & $\begin{array}{c}\text { Ammoniakemissie } \\
\text { ( } \% \mathrm{NH}_{4}-\mathrm{N} \text { gift) }\end{array}$ & $\begin{array}{l}\text { Emissiereductie } \\
\qquad(\%)\end{array}$ \\
\hline \multirow[t]{3}{*}{$14-2016$} & 1 veen ${ }^{1)}$ & Onverdund & 41,9 & \\
\hline & & $1: 0,25$ & 32,2 & 23 \\
\hline & & $1: 0,5$ & 28,9 & 31 \\
\hline \multirow[t]{3}{*}{$20-2016$} & 2 klei & Onverdund & 61,9 & \\
\hline & & $1: 0,25$ & 41,1 & 34 \\
\hline & & $1: 0,5$ & 31,7 & 48 \\
\hline \multirow[t]{3}{*}{$21-2016$} & 3 veen & Onverdund & - & \\
\hline & & $1: 0,25$ & 28,7 & \\
\hline & & $1: 0,5$ & 16,8 & \\
\hline \multirow[t]{3}{*}{$33-2016$} & 4 klei $^{2)}$ & Onverdund & 33,2 & \\
\hline & & $1: 0,25$ & 27,4 & 17 \\
\hline & & $1: 0,5$ & 11,5 & 66 \\
\hline
\end{tabular}

1) proef na 32 uur gestopt vanwege langdurige regen

2) proef na 58 uur gestopt vanwege hevige regen 
Tabel 8 Cumulatieve emissie over de gemeten periode na uitrijden van de mest als \% van de opgebrachte ammoniumstikstof $\mathrm{NH}_{4}-\mathrm{N}$ en de emissiereductie die bereikt wordt bij 1:0,33 verdunning van de mest ten opzichte van onverdunde mest in 2017.

\begin{tabular}{|c|c|c|c|c|}
\hline $\begin{array}{l}\text { Week- } \\
\text { jaar }\end{array}$ & $\begin{array}{l}\text { Proefnummer en } \\
\text { grondsoort }\end{array}$ & Verdunning & $\begin{array}{l}\text { Ammoniakemissie } \\
\text { ( } \% \mathrm{NH}_{4}-\mathrm{N} \text { gift) }\end{array}$ & $\begin{array}{c}\text { Emissiereductie } \\
\text { (\%) }\end{array}$ \\
\hline \multirow[t]{2}{*}{$20 a-2017$} & $1 \mathrm{klei}$ & Onverdund & 55,7 & \\
\hline & & $1: 0,33$ & 30,7 & 45 \\
\hline \multirow[t]{2}{*}{$20 b-2017$} & $2 \mathrm{klei}$ & Onverdund & 38,9 & \\
\hline & & $1: 0,33$ & 31,0 & 20 \\
\hline \multirow[t]{2}{*}{$25-2017$} & 3 klei $^{1)}$ & Onverdund & 45,7 & \\
\hline & & $1: 0,33$ & 41,0 & 10 \\
\hline \multirow[t]{2}{*}{$35-2017$} & $4 \mathrm{klei}$ & Onverdund & 21,8 & \\
\hline & & $1: 0,33$ & 19,9 & 9 \\
\hline
\end{tabular}

1) proef na 56 uur gestopt vanwege onstuimig weer (onweer, hevige regen) 

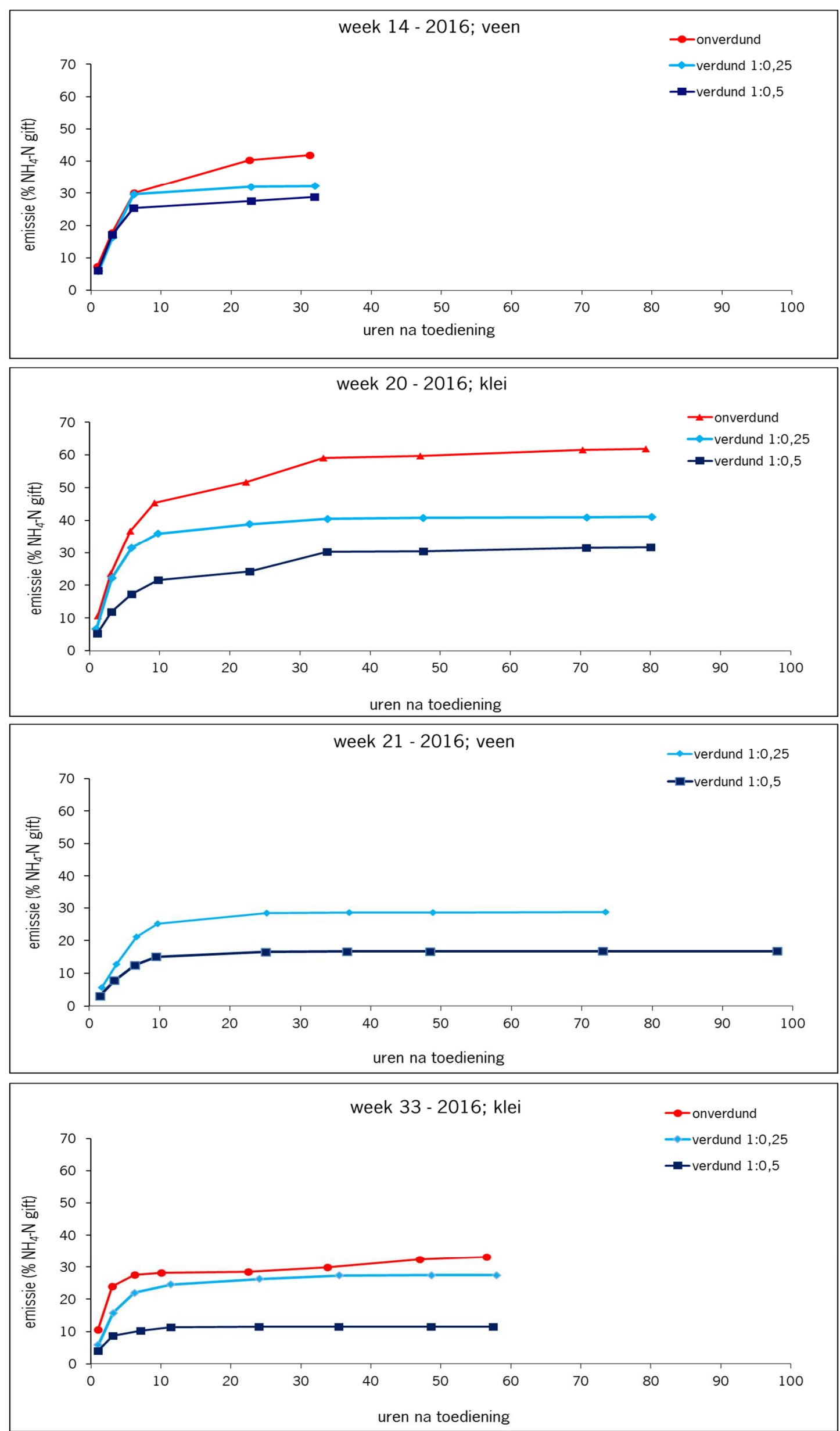

Figuur 4 Verloop cumulatieve ammoniakemissie 2016 week 14, 20, 21 en 33 na mesttoediening op veen- en kleigrond met de sleepvoetenmachine met onverdunde mest en 1:0,25 en 1:0,5 verdunde rundermest. 

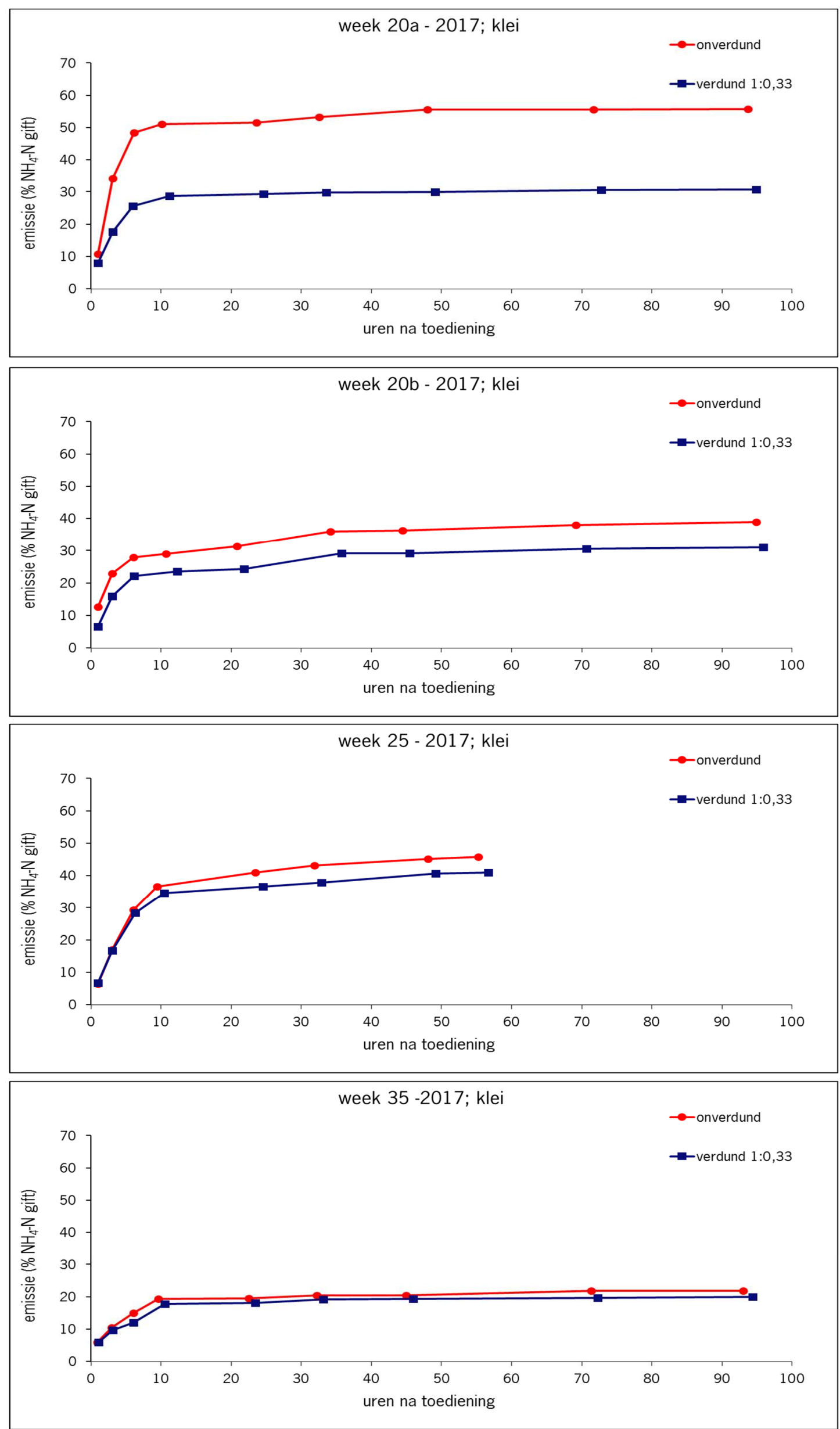

Figuur 5 Verloop cumulatieve ammoniakemissie 2017 week 20a en b, week 25 en week 35 na mesttoediening op kleigrond met de sleepvoetenmachine met onverdunde mest en 1:0,33 verdunde rundermest. 


\section{Discussie}

Voor het uitrijden van de verdunde en onverdunde mest is eenzelfde type machine toegepast om zo eventuele effecten als gevolg van de toedieningsmethode zo veel mogelijk uit te sluiten. De gebruikte machines hebben de mest in stroken op de grond zoveel mogelijk tussen het gras toegediend. Ook in deze metingen vindt de piek in de emissie plaats in de eerste uren na toediening, zoals dit ook in andere emissie-onderzoeken met dierlijke mest is aangetoond.

Uit de proeven van het onderhavig onderzoek blijkt dat meer verdunnen een lagere emissie geeft; de verschillen zijn in absolute zin niet altijd groot. Variaties in de emissies kunnen onder andere een gevolg zijn van de weersomstandigheden, bodemgesteldheid, mestverdeling, mestsamenstelling en de wijze van toediening. Zo werd bijvoorbeeld proef 1 in 2016 aangelegd onder zwaarbewolkte omstandigheden met veel wind en tegen het eind van de middag veel langdurige regen, terwijl proef 4 in 2016 onder droge warme omstandigheden werd uitgevoerd. In beide proeven waren de mestgiften, mestsamenstelling en ook bodemomstandigheden verschillend. Elke proef moet gezien worden als één meting. Verschillende proeven kunnen gezien worden als herhalingen, echter de omstandigheden waaronder gemeten is, zullen verschillend zijn voor de grond, de mest en het weer. Vanuit eerder onderzoek, uitgevoerd op grasland en bouwland, blijkt dat er veel herhalingen nodig zijn om statistisch onderbouwde uitspraken te kunnen doen over effecten van bodem- en weersomstandigheden en mestsamenstelling op de ammoniakemissie (Huijsmans et al., 2001 en 2003).

\section{Onverdunde mest}

De ammoniakemissie bij de onverdunde mest was in het onderzoek in 2016 en 2017 relatief hoog ( $46 \%$ resp. $41 \%$ ) ten opzichte van metingen in het verleden. Bij mesttoediening in stroken op de grond (sleepvoetenmachine) werd in het verleden een ammoniakemissie gevonden van gemiddeld $26 \%$ van de opgebrachte ammoniumstikstof ( $n=29 ; 9$ tot 52\%; Huijsmans \& Schils, 2009). In de onderzoeken in 2013 en 2014 (Huijsmans et al., 2015) was de ammoniakemissie gemiddeld 30\% $(n=14 ; 8$ tot $46 \%)$ en daarmee ook gemiddeld hoger dan hetgeen in het verleden gemeten is. De gemeten gemiddeld hogere ammoniakemissie is mogelijk te verklaren door hoe de mesttoediening is uitgevoerd, mestgiften en de weers-, gewas- en bodemomstandigheden. Zo werden alle proeven in 2017 uitgevoerd na de $1^{\mathrm{e}}$ snede bij relatief warme omstandigheden. Ook eventuele andere factoren kunnen een rol hebben gespeeld.

Verdunde mest

In 2013 en 2014 is ook gemeten aan met water verdunde mest toegediend met een sleepvoetenmachine (Huijsmans et al., 2015). Bij de verdunning 1 deel mest : 1 deel water (1:1) in 2013 was de gemiddelde ammoniakemissie $18 \%(n=6 ; 9$ tot $27 \%)$ en was de gemiddelde emissiereductie ca. $51 \%$. Bij een verdunning van 1 deel mest : 0,5 deel water $(1: 0,5)$ in 2014 was de gemiddelde ammoniakemissie $13 \%(n=8 ; 4$ tot $24 \%)$ en was de gemiddelde emissiereductie ca. $44 \%$. In het onderzoek in 2016 werd bij de 1:0,5 verdunning een gemiddelde emissie van 22\% ( $n=4 ; 11$ tot $32 \%$ ) gevonden en een gemiddelde emissiereductie van $48 \%$.

In het onderzoek is gekozen voor het bepalen van het effect bij verdunnen van de mest en toediening met een sleepvoetenmachine. Binnen het onderzoek is geen vergelijking gemaakt met de emissie bij zodenbemesting (of bovengronds verspreiden); voor een eventuele goede vergelijking zou de emissie bij zodenbemesting ook in de proeven gemeten moeten worden onder dezelfde omstandigheden. Voor zodenbemesting wordt momenteel een gemiddelde ammoniakemissie van $16 \%$ aangehouden, waarbij er een trend is naar 19\% (Huijsmans \& Schils, 2009). De uitgevoerde metingen in 2013-2017 geven bij de verdunningen $1: 1$ en $1: 0,5$ ammoniakemissies van $18 \%(1: 1,2013), 13 \%(1: 0,5,2014 ; n=8)$ en $22 \%(1: 0,5,2016 ; n=4)$. Het emissieniveau is bij deze verdunningen gemiddeld van een vergelijkbaar niveau als bij zodenbemesting wordt aangehouden. De gevonden gemiddelde emissie van $32 \%$ bij de 1:0,25 verdunning en $31 \%$ bij de 1:0,33 is hoger dan de andere verdunningen. 
Voor het doen van gefundeerde uitspraken over de ammoniakemissie bij verschillende methoden van toediening, verdunningen en de toepassing op verschillende grondsoorten zijn meerdere herhalingen (meetsessies over meerdere tijdstippen/seizoenen) noodzakelijk om verschillende omstandigheden in de metingen te betrekken en zo een betere schatting van de emissie te kunnen maken.

Benutting van extra beschikbare stikstof In het onderzoek van Huijsmans et al. (2015) en het voorliggende onderzoek werden gemiddelde emissiereducties van $51 \%, 45 \%$ en $25 \%$ gemeten bij de toediening met een sleepvoetenmachine en respectievelijk de verdunningen 1 deel mest : 1 deel water, 1 deel mest : 0,5 deel water en 1 deel mest : 0,25 deel water ten opzichte van de emissie bij toediening van onverdunde mest met een sleepvoetenmachine. De emissie van onverdunde mest was in deze onderzoeken gemiddeld meer dan $30 \%$ en daarmee hoger dan de huidige gehanteerde factor van $26 \%$. Op basis van deze emissieresultaten kan de hoeveelheid extra beschikbare stikstof berekend worden als gevolg van minder verlies aan ammoniak bij toedienen van verdunde mest ten opzichte van onverdunde mest. Van Schooten et al. (2017) vonden een duidelijke relatie tussen deze berekende extra beschikbare stikstof en de gemeten extra stikstofopname door het gewas voor het door hen uitgevoerde mestbenuttingsonderzoek op grasland op veengrond en kleigrond. Deze relatie werd gevonden, ondanks dat de verschillen tussen de stikstofopnames door het gewas van de behandelingen met verschillende verdunningen en die van de behandeling met onverdunde mest niet significant waren. Hierbij dient opgemerkt te worden dat gerekend is met gemiddelde emissies en emissiereducties. Beide kunnen variëren tussen proeven, evenals de stikstofbenutting tussen proeven en maaisnedes. 


\section{Conclusies en aanbevelingen}

In het uitgevoerde onderzoek is de emissie vergeleken bij het toedienen van onverdunde en verdunde mest. Het toedienen is uitgevoerd met een sleepvoetenmachine op grasland op een veen- en een kleigrond. In 2016 was de ammoniakemissie bij de toediening van de onverdunde mest gemiddeld $46 \%(n=3)$ en varieerde van 33 tot $62 \%$ van de toegediende ammoniumstikstof. Bij de verdunning 1 deel mest : 0,25 deel water $(1: 0,25)$ was de gemiddelde ammoniakemissie $32 \%(n=4)$ en varieerde van 27 tot $41 \%$. Bij 1 deel mest : 0,5 deel water $(1: 0,5)$ was de gemiddelde ammoniakemissie $22 \%$ $(n=4)$ en varieerde van 11 tot 32\%. De verdunning van 1:0,25 en 1:0,5 gaven een gemiddelde emissiereductie van respectievelijk 25 en $48 \%(n=3)$. In 2017 was de ammoniakemissie bij de toediening van de onverdunde mest gemiddeld $41 \%(n=4)$ en varieerde van 22 tot $56 \%$ van de toegediende ammoniumstikstof. Bij de verdunning 1 deel mest : 0,33 deel water $(1: 0,33)$ was de gemiddelde ammoniakemissie 31\% $(n=4)$ en varieerde van 20 tot $41 \%$. De verdunning van 1:0,33 gaf een gemiddelde emissiereductie van $21 \%(n=4)$. De gevonden reducties bij de verdunningen $1: 0,25$ en 1:0,33 waren lager en minder eenduidig dan de grotere verdunningen. Uit Huijsmans et al. (2015) en voorliggend onderzoek blijkt dat het emissieniveau bij grotere verdunningen $(1: 1$ en $1: 0,5)$ gemiddeld van een vergelijkbaar niveau is als bij zodenbemesting wordt aangehouden. In het onderzoek zijn echter geen rechtstreekse vergelijkende emissiemetingen uitgevoerd tussen zodenbemesting en toediening van met water verdunde mest met een sleepvoetenmachine.

De gemeten ammoniakemissie van de onverdunde mest was gemiddeld hoger dan in het verleden werd gevonden. Dit is mogelijk te verklaren door weers-, gewas- en bodemomstandigheden, mestsamenstelling, toedieningsmethode en eventuele andere factoren die een rol hebben gespeeld. Om hier een beter zicht op te krijgen is een verdere statistische analyse naar invloedsfactoren noodzakelijk. 


\section{Literatuur}

Denmead, O.T., 1983. Micrometeorological methods for measuring gaseous losses of nitrogen in the field, in: J.R. Freney \& J.R. Simpson (eds), Gaseous loss of nitrogen from plant-soil systems, Martinus Nijhoff/Dr. W. Junk Pub., Den Haag.

Huijsmans, J.F.M., J.M.G. Hol \& M.M.W.B. Hendriks, 2001. Effect of application technique, manure characteristics, weather and field conditions on ammonia volatilization from manure applied to grassland. Netherlands Journal of Agricultural Science 49: 323-342.

Huijsmans, J.F.M., J.M.G. Hol \& G.D. Vermeulen, 2003. Effect of application method, manure characteristics, atmosphere and field conditions on ammonia volatilization from manure applied to arable land. Atmospheric Environment 37: 3669-3680.

Huijsmans, J.F.M. \& R.L.M. Schils, 2009. Ammonia and nitrous oxide emissions following fieldapplication of manure: state of art measurements in the Netherlands. Proceedings 655, International Fertiliser Society, $35 \mathrm{pp}$.

Huijsmans, J.F.M., J.M.G. Hol \& H.A. van Schooten, 2015. Ammoniakemissie bij toediening van verdunde mest met een sleepvoetenmachine op grasland. Plant Research International, Wageningen UR, Wageningen, rapport 633, 33 pp.

Ryden, J.C. \& J.E. McNeill, 1984. Application of the micrometeorological mass balance method to the determination of ammonia loss from a grazed sward. Journal of the Science of Food and Agriculture 35: 1297-1310.

Van Schooten, H.A., K.M. van Houwelingen \& J.F.M. Huijsmans, 2015. Effect van alternatieve mestaanwendingsmethoden op mestbenutting door gras. Resultaten van twee oriënterende veldproeven. Livestock Research, Wageningen UR, Wageningen, rapport 912, 39 pp.

Van Schooten, H.A., J.F.M. Huijsmans \& K.M. van Houwelingen, 2017. Benutting van met water verdunde mest aangewend met sleepvoetenmachine op grasland. Eénjarige veldproeven op kleien veengrond 2016. Wageningen Livestock Research, Rapport 1084, 38 pp. 


\section{Bijlage 1 Weersomstandigheden tijdens de metingen in 2016}

Weersomstandigheden week 14-2016 (06-04-2016/08-04-2016).
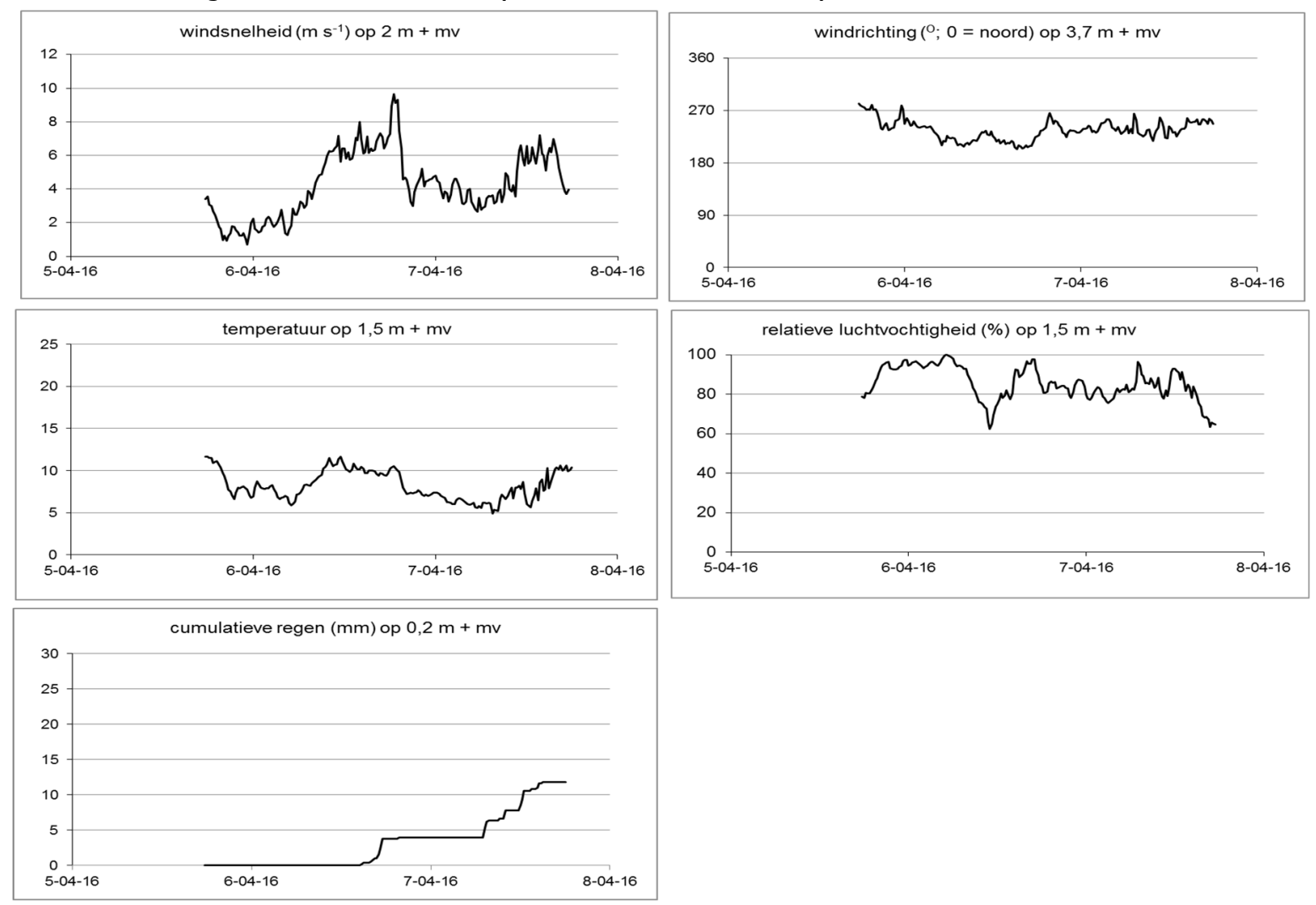

Weersomstandigheden week 20-2016 (17-05-2016/20-05-2016).
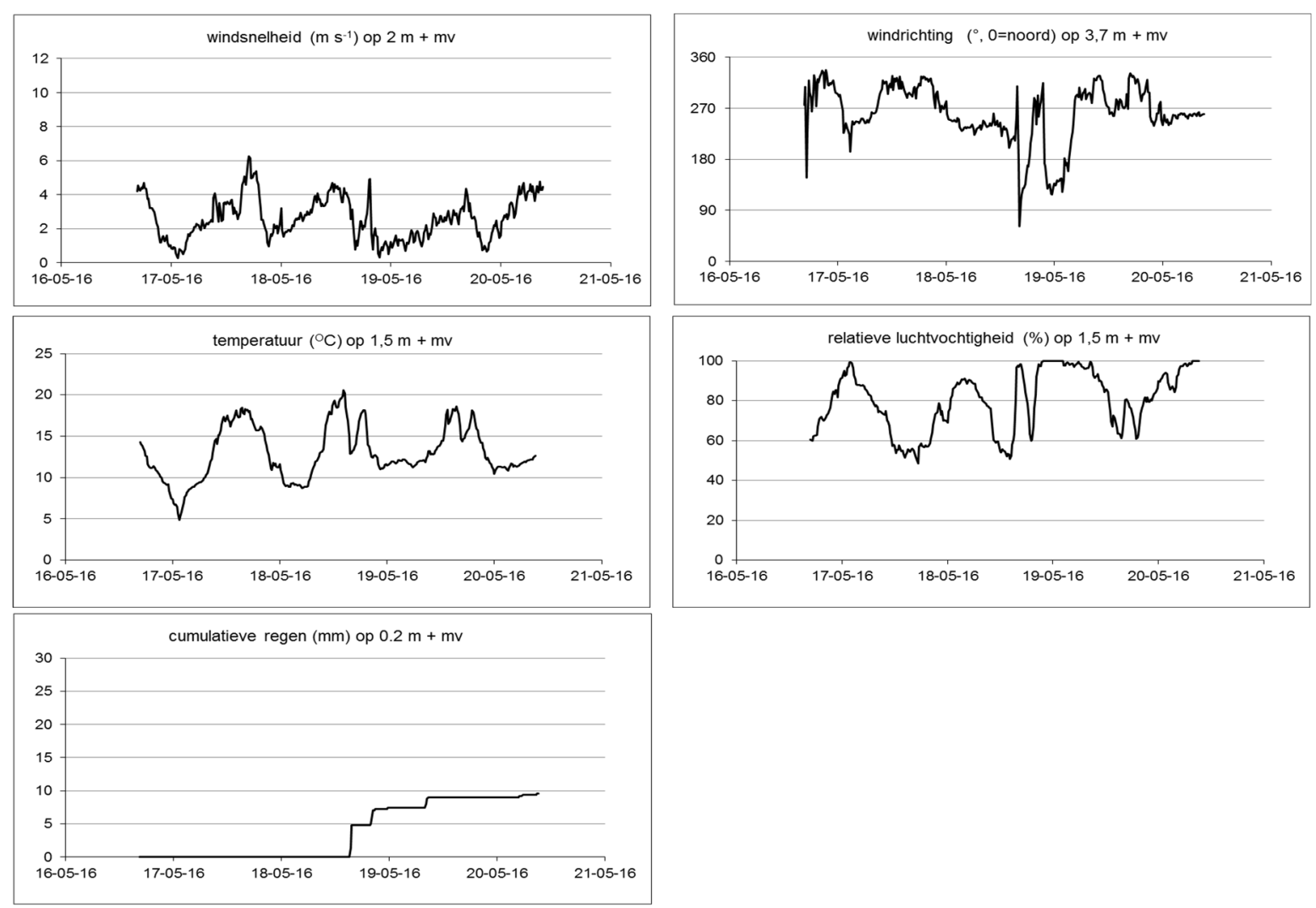
Weersomstandigheden week 21-2016 (24-05-2016/27-05-2016).
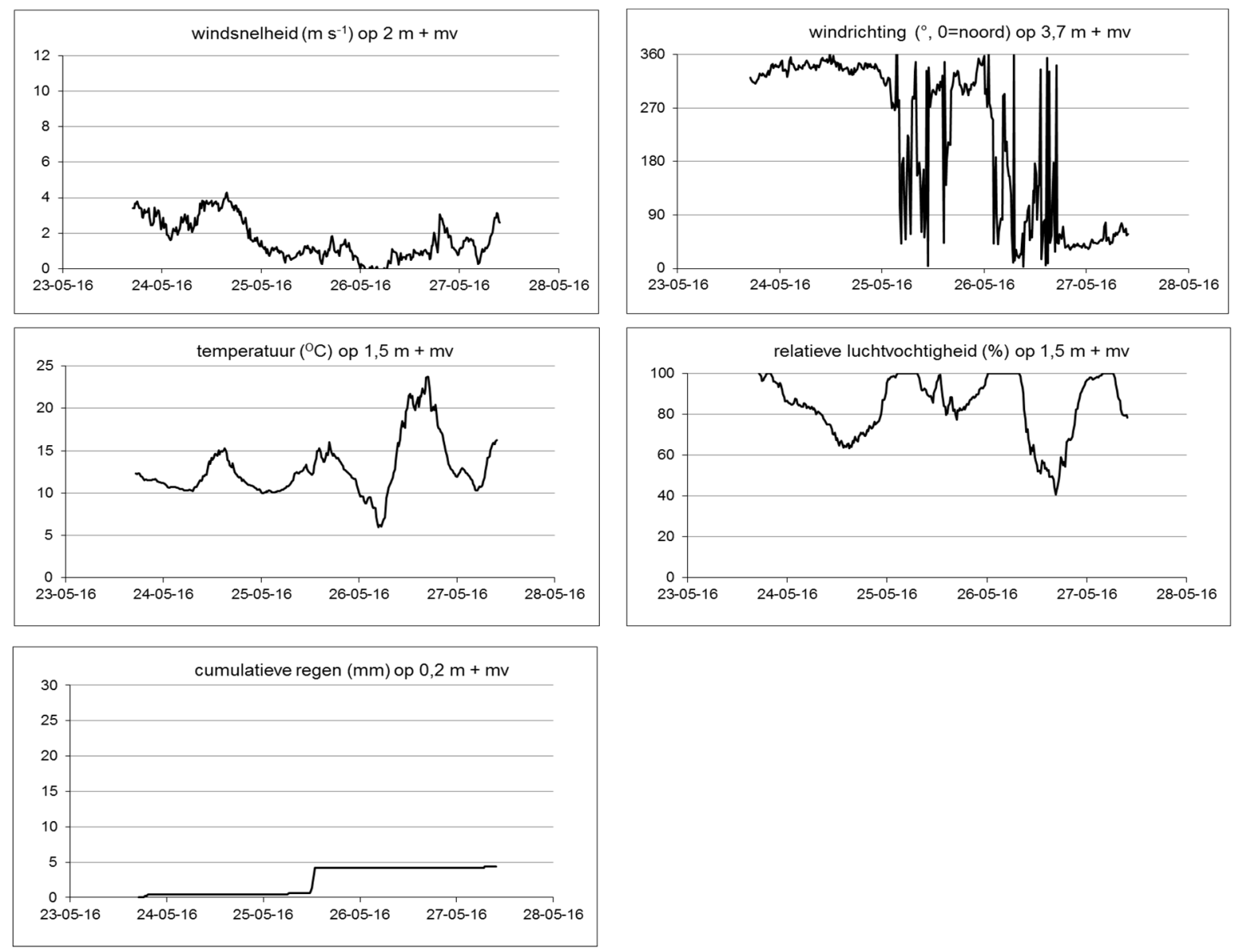

Weersomstandigheden week 33-2016 (19-08-2016/23-08-2016).
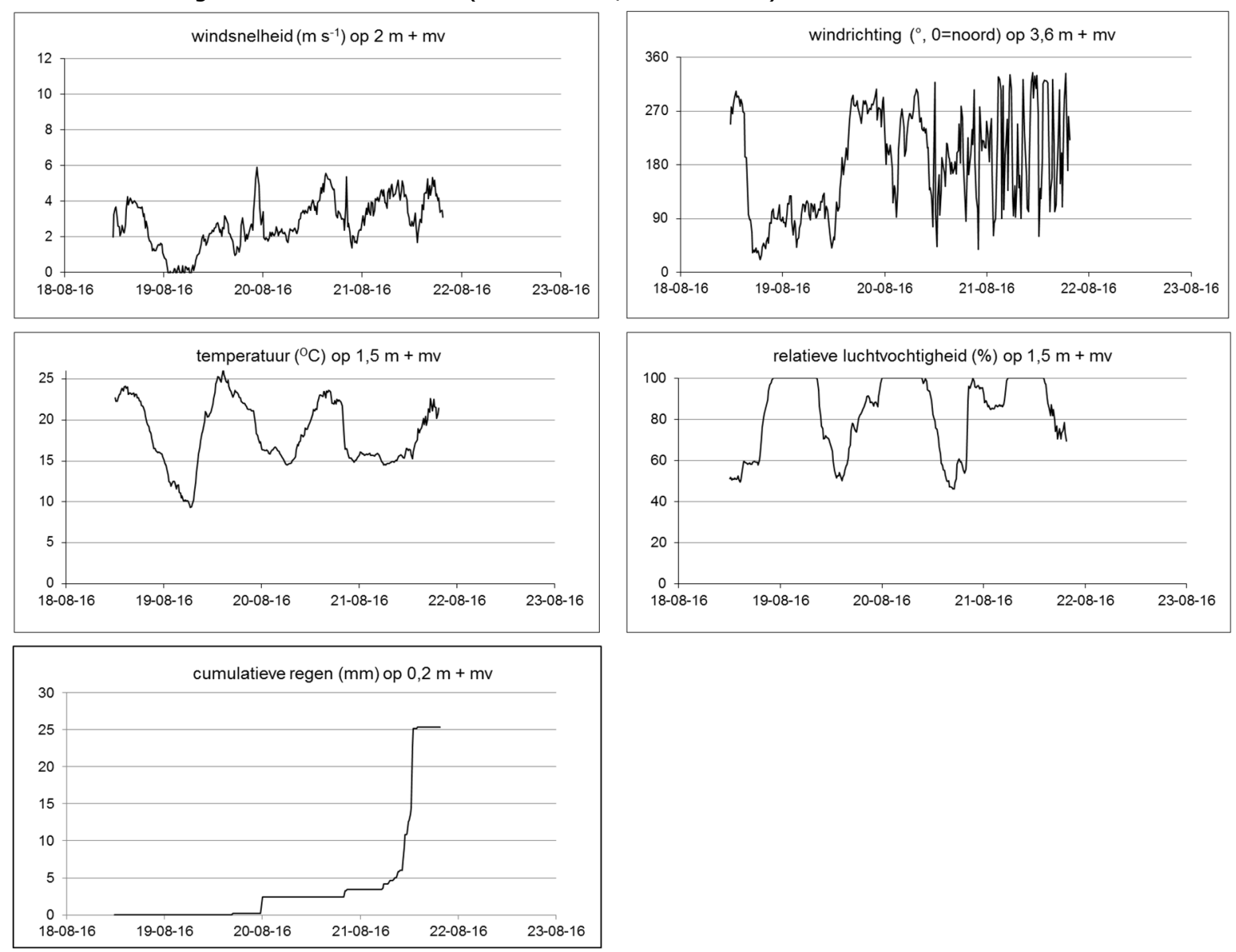


\section{Bijlage 2 Weersomstandigheden tijdens de metingen in 2017}

Weersomstandigheden week 20a en b-2017 (16-05-2017/24-05-2017).
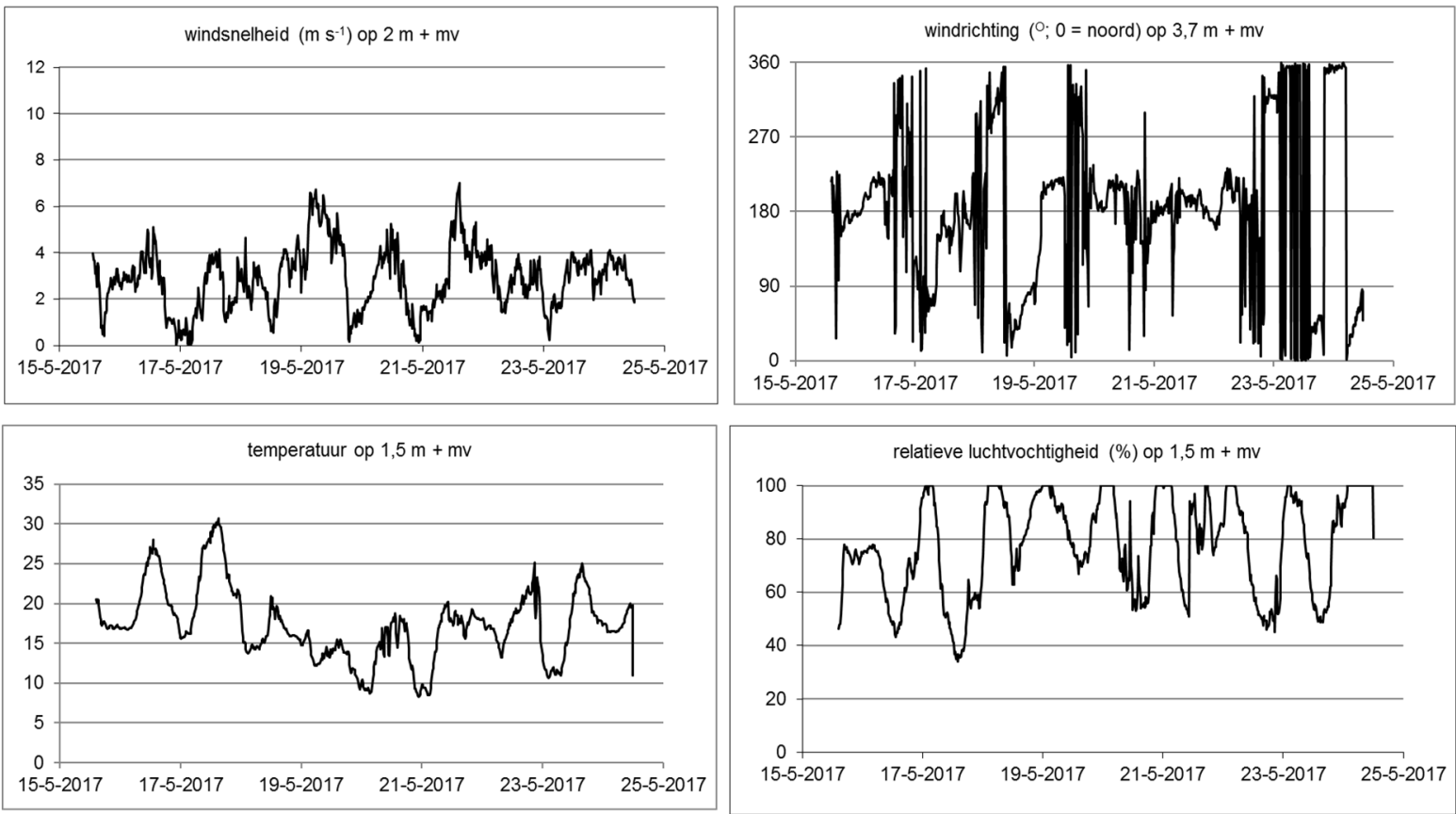

Weersomstandigheden week 25-2017 (19-06-2017/23-06-2017).
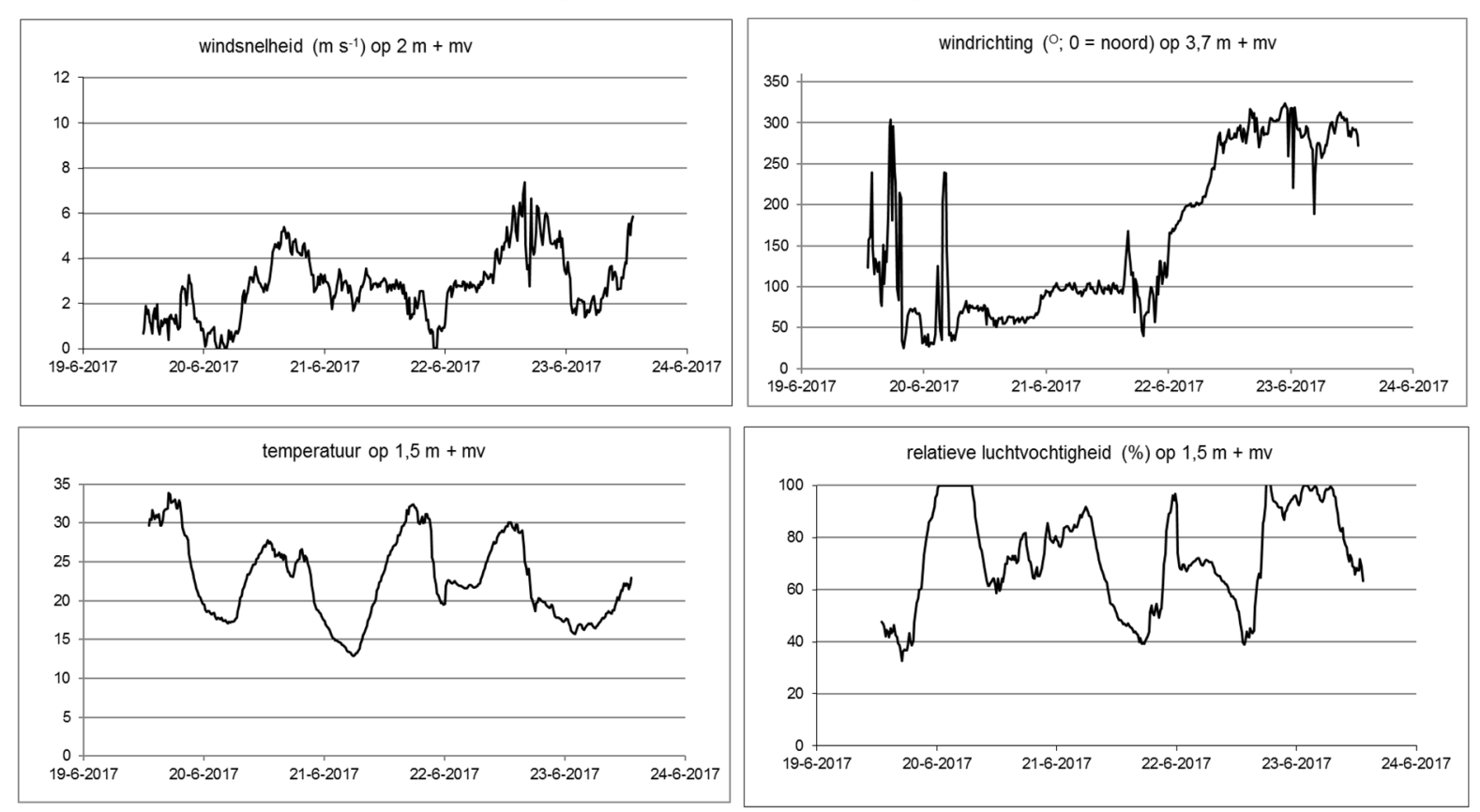
Weersomstandigheden week 35-2017 (31-08-2017/4-09-2017).
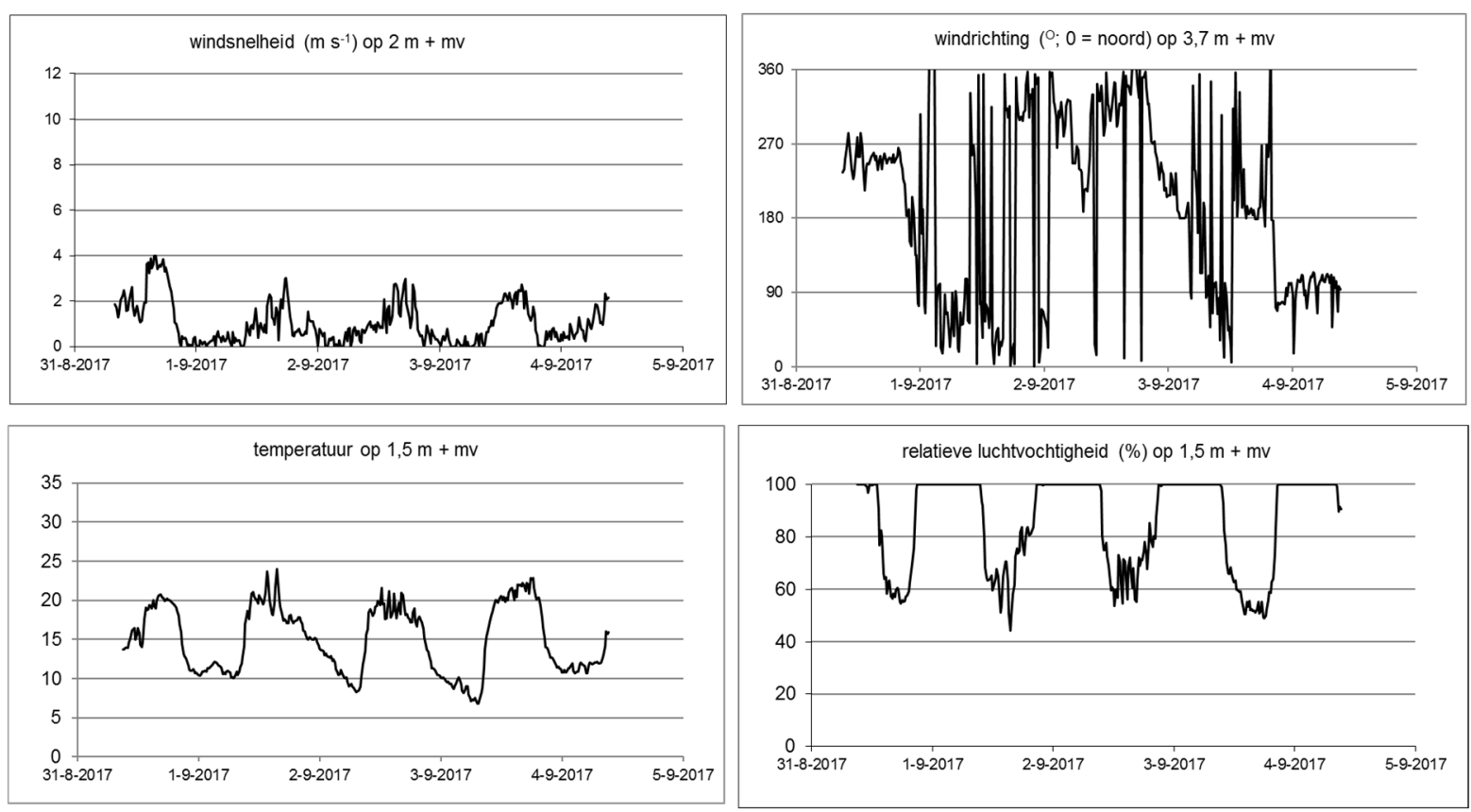
Correspondentie adres voor dit rapport: Postbus 16

6700 AA Wageningen

T 0317486001

www.wur.nl/plant-research

Wageningen Plant Research Rapport 754
De missie van Wageningen University \& Research is 'To explore the potential of nature to improve the quality of life'. Binnen Wageningen University \& Research bundelen Wageningen University en gespecialiseerde onderzoeksinstituten van Stichting Wageningen Research hun krachten om bij te dragen aan de oplossing van belangrijke vragen in het domein van gezonde voeding en leefomgeving. Met ongeveer 30 vestigingen, 5.000 medewerkers en 10.000 studenten behoort Wageningen University \& Research wereldwijd tot de aansprekende kennisinstellingen binnen haar domein. De integrale benadering van de vraagstukken en de samenwerking tussen verschillende disciplines vormen het hart van de unieke Wageningen aanpak. 


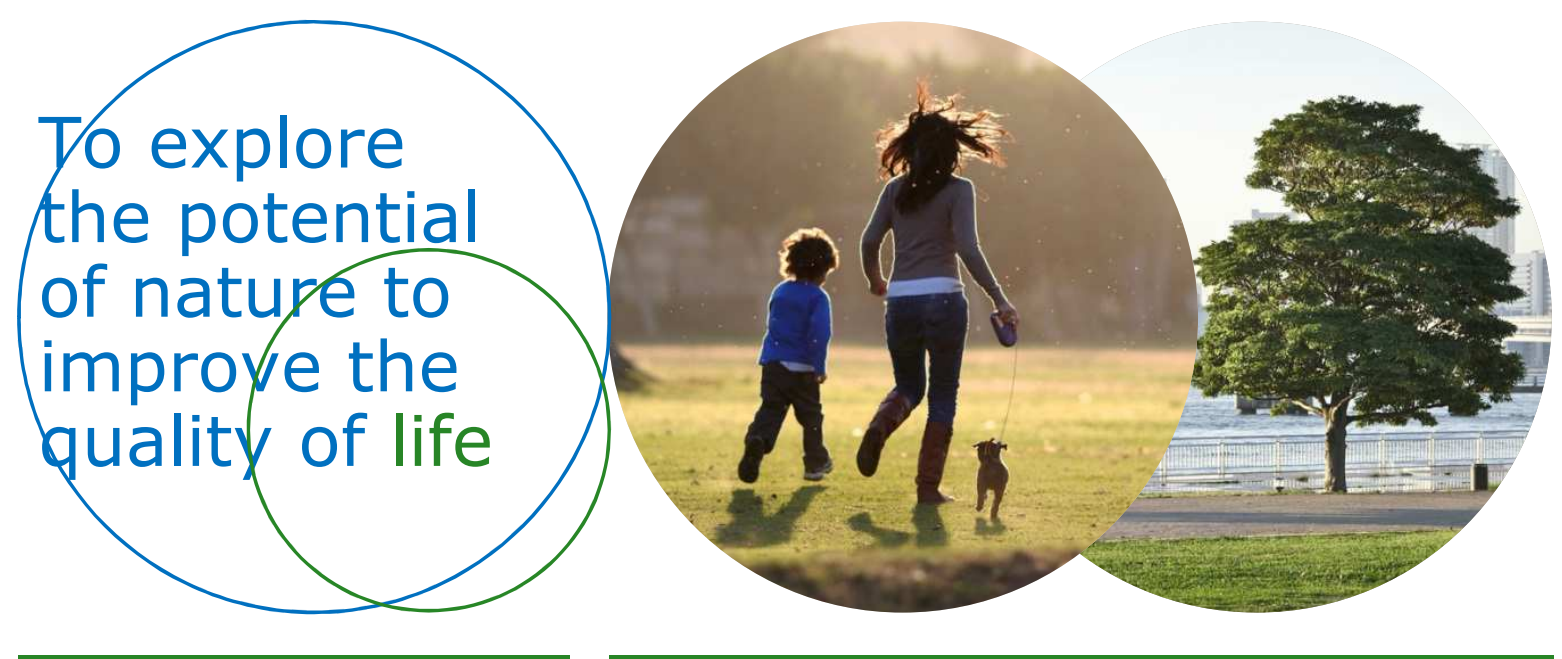

Correspondentie adres voor dit rapport: Postbus 616

6700 AP Wageningen

T 0317480700

www.wur.nl/plant-research

Rapport 754
De missie van Wageningen University \& Research is 'To explore the potential of nature to improve the quality of life'. Binnen Wageningen University \& Research bundelen Wageningen University en gespecialiseerde onderzoeksinstituten van Stichting Wageningen Research hun krachten om bij te dragen aan de oplossing van belangrijke vragen in het domein van gezonde voeding en leefomgeving. Met ongeveer 30 vestigingen, 5.000 medewerkers en 10.000 studenten behoort Wageningen University \& Research wereldwijd tot de aansprekende kennisinstellingen binnen haar domein. De integrale benadering van de vraagstukken en de samenwerking tussen verschillende disciplines vormen het hart van de unieke Wageningen aanpak. 